\title{
The Role of Nanofluids and Renewable Energy in the Development of Sustainable Desalination Systems: A Review
}

\author{
Tejvir Singha, Muataz Ali Atieh ${ }^{a \& b}$, Tareq Al-Ansaria, Abdul Wahab Mohammadc and Gordon \\ McKay $^{\mathbf{a}^{*}}$ \\ a Division of Sustainable Development, College of Science and Engineering, Hamad Bin Khalifa University, \\ Qatar Foundation, Doha, Qatar. \\ b Qatar Environment and Energy Research Institute (QEERI), Hamad bin Khalifa University (HBKU), Qatar \\ Foundation, PO Box 5825, Doha, Qatar \\ c Department of Chemical and Process Engineering, University Kebangsaan Malaysia (The National \\ University of Malaysia), 43600 UKM Bangi, Selangor, Malaysia \\ * Corresponding Authors: Email: gmckay@mail.hbku.edu.qa
}

\begin{abstract}
Desalination accounts for $1 \%$ of the total global water consumption and is an energy-intensive process, with the majority of operational expenses attributed to energy consumption. Moreover, at present, a significant portion of the power comes from traditional fossil fuel-fired power plants and the greenhouse gas emissions associated with power production along with concentrated brine discharge from the process, pose a severe threat to the environment. Due to the dramatic impact of climate change, there is a major opportunity to develop sustainable desalination processes to combat the issues of brine discharge, greenhouse gas emissions along with a reduction in energy consumption per unit of freshwater produced. Nanotechnology can play a vital role to achieve specific energy consumption reduction as nanofluids application increases the overall heat transfer coefficient enabling the production of more water for the same size desalination plant. Furthermore, concentrated brine discharge harms the marine ecosystems, and hence, this problem must also be solved to support the objective of sustainable desalination. Several studies have been carried out in the past several years in the field of nanotechnology applications for desalination, brine treatment and the role of renewable energy in desalination. This paper aims to review the major advances in this field of nanotechnology for desalination. Furthermore, a hypothesis for developing an integrated solar thermal and nanofluid sustainable desalination system, based on the cyclic economy model is proposed.
\end{abstract}

Keywords: thermal desalination; reverse osmosis; advanced heat transfer fluids; sustainable desalination practices; integrated solar thermal nanofluids based desalination

\section{Highlights}

1. There is an immediate need to develop cost-effective renewable desalination.

2. Nanofluids lead to enhancement in overall heat transfer coefficient

3. Reverse Osmosis, coupled with Photovoltaic, is cost-competitive.

4. Impacts of brine discharge can be reduced through a cyclic economy model.

5. Solar thermal with nanofluids allows desalination with zero emissions. 


\section{Introduction}

Water is critical for sustaining life on earth. The World Resources Institute reports that by 2040, 33 nations will face severe water challenges. Moreover, "World Data Lab" estimated water scarcity globally and reported that almost 2.327 Billion people globally are living under water-scarce areas at present which is expected to surge up to 2.7 Billion people by 2030 [1]. As such, the United Nations has established the "Sustainable Development Goals" (SDGs) which serve to address critical issues facing modern human civilization such as those pertaining to water, food and energy security. The technologies outlined in this paper, which includes solar desalination systems for the provision of clean water, combating climate change and marine life, thus targeting SDGs 6,13 and 14 . Based on recent data from the World Health Organization, the global population will reach 9.3 billion in a "business as usual" scenario by 2050, which in turn will increase food demand by $60 \%$ while the urbanized population is expected to surpass 6.3 billion (UN DESA, 2011). Such pressures will likely exacerbate the rate at which freshwater resources will face severe stress. In 2019, there are at least 1.8 billion people who are devoid of reliable access to water, which is fit for human consumption [2]. If the current trend continues, water demand will surpass its supplies by $40 \%$ by the year 2031 [3]. Currently, global desalination produces 100 million cubic meters per day, which is less than $1 \%$ of the total water consumed globally [4]. As per IDA (International Desalination Association - a United Nations recognized body), there are 19744 desalination plants worldwide with a combined capacity of almost 100 million cubic meters per day situated in over 150 countries [5]. The desalination capacity is distributed globally with nearly $47.5 \%$ share in MENA region, $18.4 \%$ in East Asia and Pacific, $11.9 \%$ in North America, $9.2 \%$ in Western Europe, 5.7\% in Latin America and Caribbean, 3.1\% in Southern Asia, 2.4\% in Eastern Europe and Central Asia and 1.9\% in Sub-Saharan Africa [6]. The maximum share of these desalination capacities comes through Reverse Osmosis $(>65 \%)$. The total brine production from these desalination plants globally exceeds 141 million cubic meters per day, which is $141 \%$ higher than the total desalinated water production per day [6].

In order to achieve the objective of fulfilling the potable water demand for all the earth's population, there is a need to expand global desalination from oceans (the source of $97 \%$ of the world's water resources). Water scarcity can be classified in categories ranging from physical water scarcity to an economical one. Economical water scarcity is defined as the condition in which it is not economically feasible to extract fresh water from existing sources. Figure 1 illustrates the degree of water scarcity as a function of the country. Also, as estimated, the freshwater demand is expected to surge significantly, and Figure 2 illustrates this growth by comparing freshwater demand for various sectors between 2000 and 2050. The indicator 6.4.2 of SDG 6 defines water stress as the ratio of total freshwater withdrawn (TFWW) and the difference of total renewable freshwater withdrawn (TRWR) and environmental flow requirements (EFR) as per relation 1. The water stress is calculated for several countries by utilizing relationship 1 which shows that the level of water stress is the highest in North Africa (112.2\%) followed by Central Asia (79\%) and other regions, with lowest water stress reported in Melanesia, Micronesia and Polynesia combined (0.1\%) [7].

Water Stress $(\%)=\frac{(\text { TFWW }) \times 100}{\text { TRWR-EFR }}$

Where,

TFWW: Total freshwater withdrawn

TRWR: Total renewable freshwater resources

EFR: Environmental Flow requirements which are defined as a quantity, timing, and quality of water flows required to sustain freshwater supplies for maintaining life.

The in-depth analysis by the FAO (Food and Agriculture Organization) showed that at present, 22 countries are facing severe water stress (above 70\%) followed by 32 countries with water stress levels between 25 and $70 \%$. Moreover, out of the total of 15 countries with water stress levels higher than $100 \%$, four countries have water stress level beyond $1000 \%$. These four countries are the United Arab Emirates, Kuwait, KSA (Kingdom of Saudi Arabia) and Libya. Generally, the water stress levels are surging globally since the past two decades due to increased economic activity and 
enhancement in living standards. However, Europe is an exception where water stress levels are found to be diminishing on account of enhancement in water use efficiency and shifting economic activity sectors, which consume less water [7].

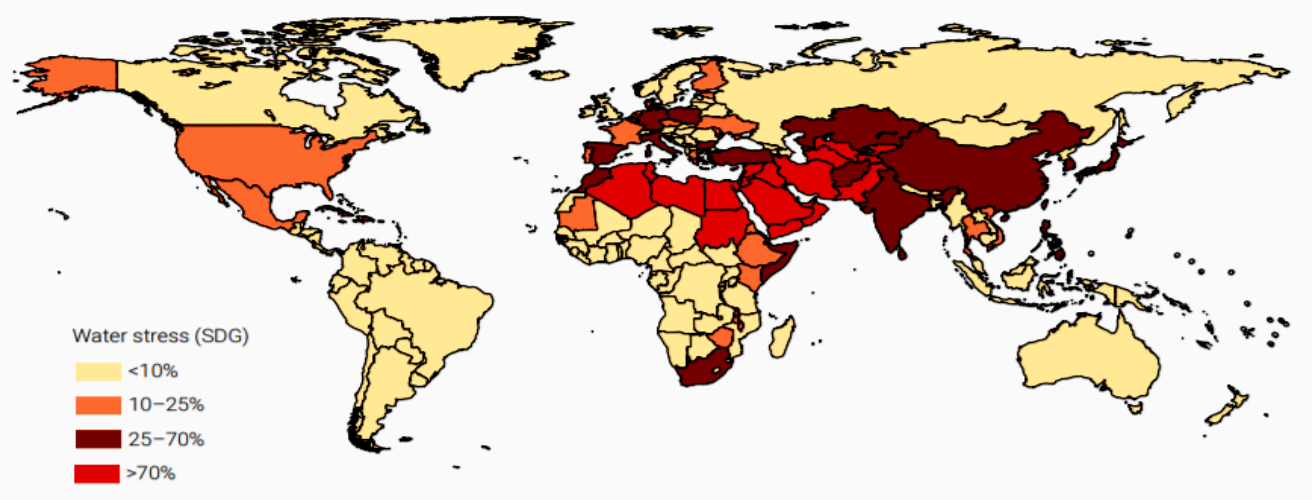

Figure 1. Levels of water stress by country (2000-2015) [7]. ( 2018 IWMI and FAO Aquastat).

Safe and potable water (free from chemical, microbial and physical impurities) is required for municipal demands, in addition to industrial, petrochemicals, pharmaceuticals and food processing. Desalination is a favoured technology for countries which do not have an abundance of freshwater reserves. This is because although desalination is energy-intensive and poses multiple environmental concerns due to brine discharge, they are drought-proof compared with their freshwater resources, which depend on an annual or multi-year precipitation, rainwater runoff, and other recharge rates. Incidentally, the desalination's energy requirements also contribute to greenhouse gas emissions, depending on the source of energy generation, i.e. if powered by hydrocarbons. In the past few years, the cost of desalinated water has declined. However, desalination is the most energy-intensive means to obtain fresh water. Therefore, there is a need for new methods which limit environmental burdens associated with the more conventional types of seawater desalination techniques (thermal and membrane desalination techniques), and they must fulfil the growing demand for potable water, simultaneously.

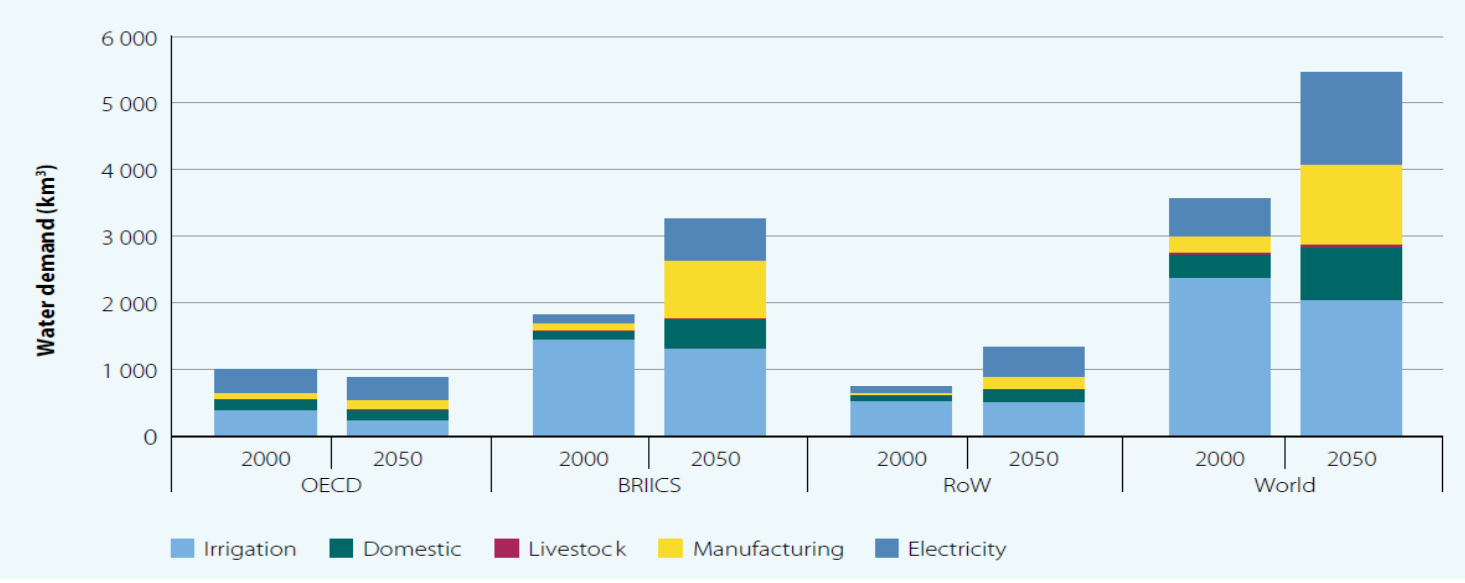

Figure 2.Global freshwater demand: baseline scenario, 2000 and 2050 [2]. (C UNESCO 2016). (OECD: Organization for Economic Co-operation and Development; ROW: Rest of the World; BRIICS: Brazil, Russia, India, China and South Africa).

Furthermore, sustainable desalination is of prime concern, too as with the increasing desalination capacity globally, the issue of brine production and discharge is creating grave concern for the sea ecosystems, and this issue must be addressed with the utmost urgency. As previously 
discussed the quantity of brine production is almost $141 \%$ of the total global desalination capacity, and it is damaging the oceans. Sustainability, as defined by Tester et al. [8-9], is "a dynamic harmony between the equitable availability of energy-intensive goods and services to all people and the preservation of the earth for future generations". In order to protect the oceans from further damage and keep them in good health to maintain the ecosystem services for future generations, a brine management solution must be introduced. Moreover, energy consumption constitutes the majority of operational expenses for desalination projects. Hence, it is crucial to obtain this required energy sustainably through alternative means. Nanotechnology, on the other hand, allows a reduction in energy consumption for membranes as well for the operation of thermal desalination systems, which allows either a reduction in $\mathrm{CO}_{2}$ emissions (if power is generated through hydrocarbons) or efficient utilization of renewable energy generating systems. Sustainable desalination is the basic necessity, and it includes two facets: appropriate brine management and providing power through sustainable means. Nanotechnology supports the second facet of sustainable desalination. Desalination costs have declined steadily throughout recent decades, increasing its competitiveness in comparison to other water supply alternatives. Electricity expenses vary from $30 \%$ to $60 \%$ of the cost of operating desalination facilities which in turn increases the uncertainty risk due to continually rising electricity prices causing the price cubic meter of desalinated water also to increase accordingly [10]. This uncertainty in pricing and fluctuations impede the implementation of large-scale desalination facilities. As such, research is required in order to develop new integrated technologies based on renewable energy and new materials which can lead to highly efficient, more sustainable and reliable water producing systems. This paper reviews, some of the most promising and relevant desalination technologies, including new advances in the technology and opportunities for the development of a new integrated desalination infrastructure. The focus of a new desalination infrastructure will be centred on the integration of desalination technologies with advanced heat transfer fluids (nanofluids) and traditional solar thermal as well as newly developed PV solar thermal technologies. The novelty of this review is the comprehensive discussion on recent advancements in energy and desalination systems with provision to develop integrated solar thermal and nanofluid sustainable desalination system.

\section{Assessment of Desalination Processes}

The complete desalination process consists of three different stages: Pre-treatment of raw seawater, desalination through various techniques and post-treatment. Apart from these three main processes, other activities include the intake mechanism of raw seawater, the discharge of toxic brine and permeate to the respective destinations.

\subsection{Pre-treatment of intake water}

Seawater contains various impurities and hence, in order to avoid the problem of scaling, corrosion, fouling and foaming, chemical pre-treatment of raw seawater is obligatory. Once water is extracted from the sea, it must be pre-treated in order to mitigate specific detrimental effects during the process. Seawater consists of various salt compositions and chemicals which are harmful to plant machinery and which also slow down the process, thereby resulting in increased economic costs and material losses. Table 1 lists different pollutants, their causes and pre-treatment techniques used to treat them.

Table 1. Typical seawater desalination pre-treatment processes [11-12]. (Copyright (C 2018 Lenntech B.V.).

\begin{tabular}{|c|c|c|}
\hline Fouling & Cause & Appropriate Pre-treatment \\
\hline Biological & $\begin{array}{l}\text { Bacteria, Microorganisms, } \\
\text { Protozoan }\end{array}$ & Chlorination \\
\hline Colloidal & $\begin{array}{l}\text { Organic and inorganic complexes, } \\
\text { colloidal particles, micro-algae }\end{array}$ & $\begin{array}{l}\text { Coagulation+ filtration } \\
\text { Optional: flocculation/sedimentation }\end{array}$ \\
\hline
\end{tabular}




\begin{tabular}{lll}
\hline Mineral & $\begin{array}{l}\text { Barium, Calcium, Magnesium, or } \\
\text { Strontium sulphates or carbonates }\end{array}$ & Anti scalant dosing; Acidification \\
Organic & $\begin{array}{l}\text { Natural Organic Matter (NOM): Fulvic } \\
\text { and Humic acids, biopolymers }\end{array}$ & $\begin{array}{l}\text { Coagulation + filtration + Activated carbon adsorption; } \\
\text { Coagulation + Ultra-filtration }\end{array}$ \\
Particle & $\begin{array}{l}\text { Sand, Clay (Turbidity \& Suspended } \\
\text { Solids) }\end{array}$ & $\begin{array}{l}\text { Filtration } \\
\text { Oxidant }\end{array}$ \\
& $\begin{array}{l}\text { Chlorine, Ozone, } \mathrm{KMnO}_{4} \\
\text { Oxidant Scavenger dosing: Sodium (meta) bisulphite }\end{array}$ \\
\hline
\end{tabular}

\subsection{Desalination technologies}

Desalination technologies can be broadly categorized into either single-phase or phase transition processes [13-14]. As the name indicates the technologies in which there is a change of phase or transition between the different phases of matter such as liquid/gas, solid/gas or liquid/solid are classified under Phase change category and vice versa.

Table 2. Classification of general desalination technologies [13-14].

\begin{tabular}{|c|c|c|c|}
\hline $\begin{array}{l}\text { Separation } \\
\text { Mechanism }\end{array}$ & Energy & Process & Technology \\
\hline \multirow{5}{*}{ Phase Change } & \multirow{4}{*}{ Thermal+Electrical } & Evaporation & $\begin{array}{l}\text { Multi-Stage Flash (MSF), Multi-Effect Distillation } \\
\text { (MED), Thermal Vapour Compression (TVC), Solar } \\
\text { distillation, Ocean Thermal Energy Conversion }\end{array}$ \\
\hline & & & (OTEC) $\quad$ (Liquid/Gas-phase change) \\
\hline & & Crystallization & $\begin{array}{c}\text { Freezing and Formation of } \\
\text { Hydrates(Liquid/Solid-phase change) }\end{array}$ \\
\hline & & $\begin{array}{l}\text { Evaporation and } \\
\text { filtration }\end{array}$ & $\begin{array}{c}\text { Membrane Distillation (MD) (Liquid/Gas phase } \\
\text { change) }\end{array}$ \\
\hline & Mechanical & Evaporation & $\begin{array}{c}\text { Mechanical Vapour Compression (MVC) } \\
\text { (Liquid/Gas phase change) }\end{array}$ \\
\hline \multirow{4}{*}{$\begin{array}{l}\text { No phase } \\
\text { change (Single } \\
\text { Phase) }\end{array}$} & Mechanical & Filtration & $\begin{array}{c}\text { Reverse Osmosis (RO) and Nanofiltration (Solute } \\
\text { diffusion) }\end{array}$ \\
\hline & & Selective & \\
\hline & Electrical & $\begin{array}{l}\text { filtration (Ionic } \\
\text { migration) }\end{array}$ & Electro Dialysis (ED) (Electrochemical separation) \\
\hline & Chemical & Exchange & $\begin{array}{l}\text { Ion Exchange (IX) and Extraction (Electrochemical } \\
\text { separation) }\end{array}$ \\
\hline
\end{tabular}

Table 2 lists the most recent desalination technologies which are classified based on the separation mechanisms and their energy utilization processes. Furthermore, table 2 mentions about the working principle of phase transition (if any) involved during the process. There lies a phase transition in evaporation and crystallization based desalination systems. The respective transition is mentioned in table 2 against the designated technologies.

Furthermore, considering, the share of each technology in global desalination, it can be deduced from figure 3 that Reverse Osmosis (RO), Multi-Stage Flash (MSF) and Multi-Effect Distillation (MED) account for more than $90 \%$ of the total desalination capacity [6]. MED is less energy-intensive as compared with MSF, and the OPEX of MED is at par with RO technology with some additional benefits of thermal desalination. Hence, to design sustainable desalination system, MED is considered as a suitable technology. 

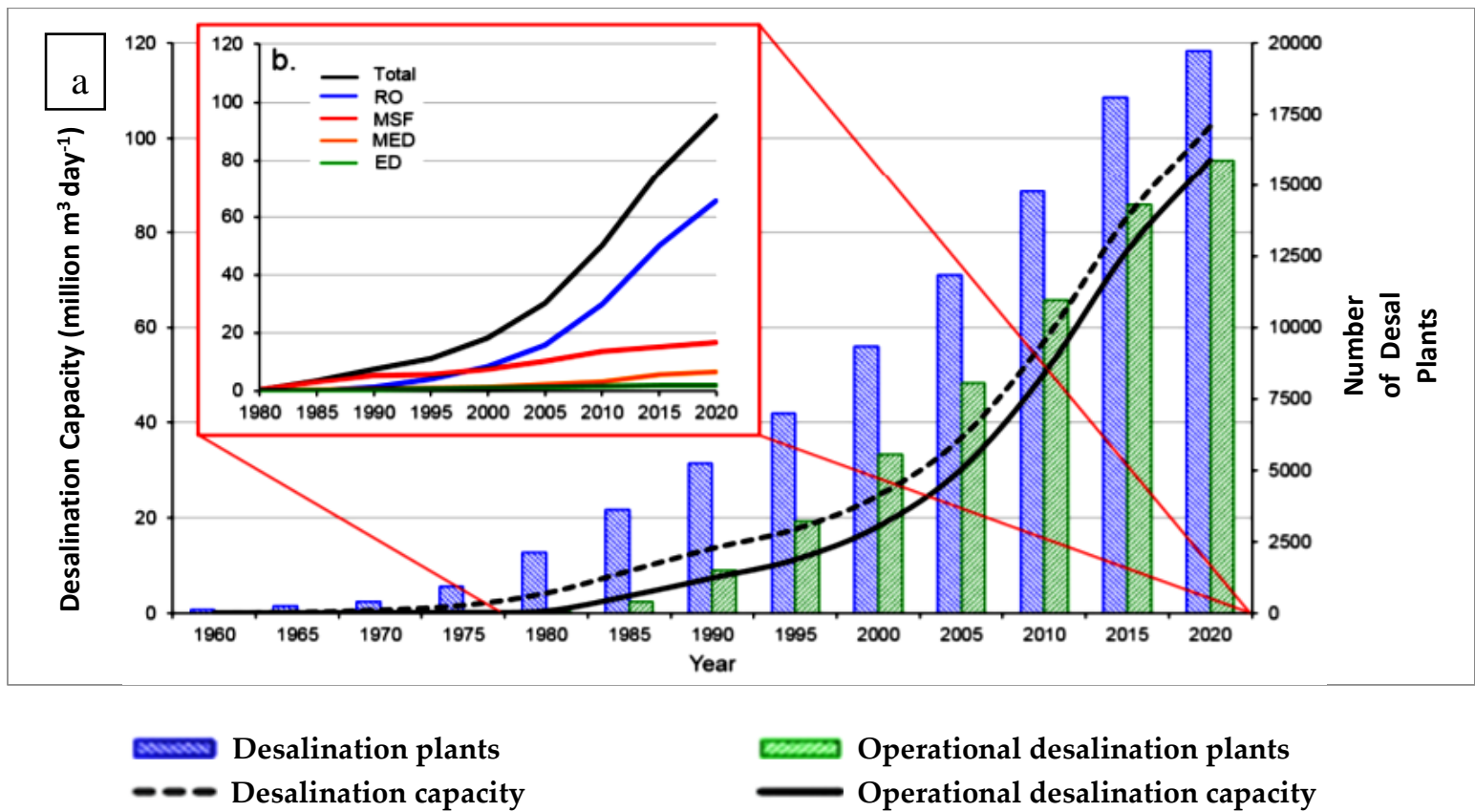

Figure 3. (a) Desalination plants worldwide and (b) share of different desalination processes [6].

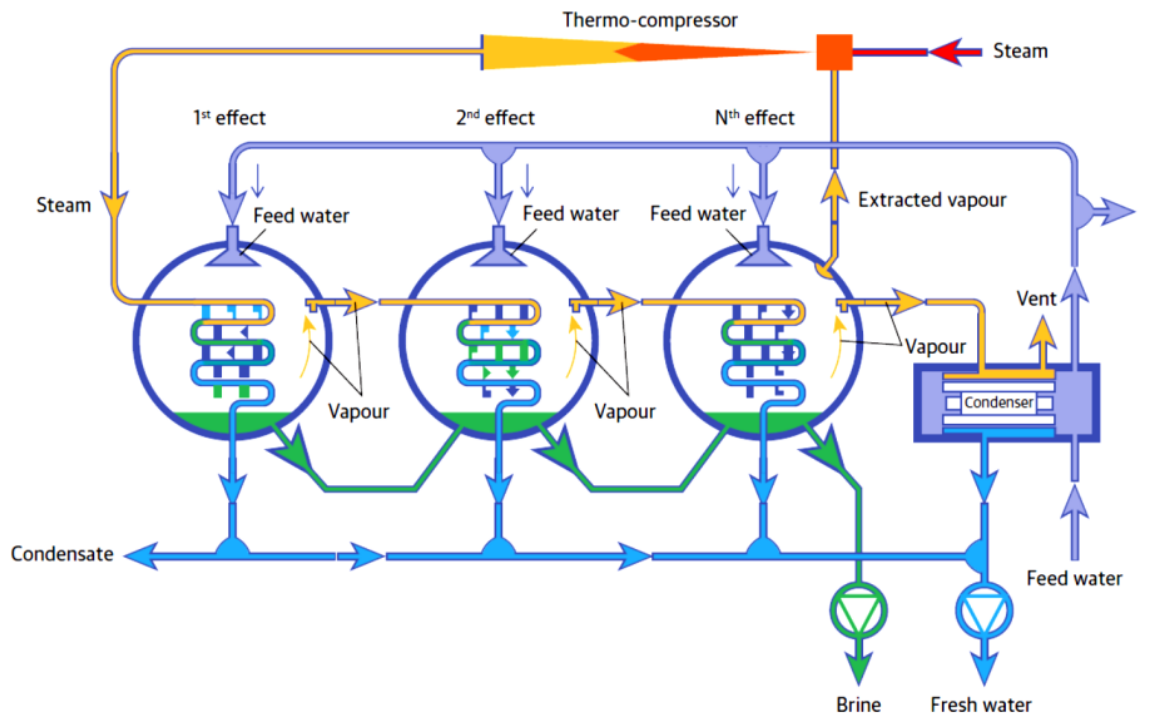

Figure 4. Schematic of MED technology [15, 39]. [@ 2019 International Bank for Reconstruction and Development / The World Bank].

MED is a technique which operates on the principle of reduced pressures in each successive stage or effect. In this process, illustrated in Figure 4, seawater is sprayed onto the heat source in the first effect where heated vapours are transferred to the following effect which operates at a lower pressure than that of the first effect. Thus, the vapours of the first effect act as a heat source for the second effect and the process moves on continuously for all successive effects. The freshwater vapours from each effect are collected at the end after condensation and brine is discharged out from the bottom of each effect. MED operates in the temperature range of $65^{+} / 5^{\circ} \mathrm{C}$ and yields a better GOR (Gain output ratio) than MSF [15].

\subsection{Post-Treatment of Water Permeate}

Post-treatment of desalinated water is crucial as the permeate produced is considered as active water (stripped of the majority of minerals and high in $\mathrm{pH}$ ) and is not fit for domestic applications. the desalinated water is utilized for drinking, it will lead to severe health problems, including 
demineralization of bones. Hence, the post-treatment is necessary, and the techniques utilized for post-treatment depends on the final application of the permeate. The most common post-treatment process involves remineralization by either calcium carbonate or calcium hydroxide with $\mathrm{CO}_{2}$ [17]. For drinking water, the desalinated water from membranes can be passed through second pass RO to reduce boron and sodium chloride concentration followed by remineralization. The irrigation water must pass the test for Sodium Adsorption Ratio (SAR), electrical conductivity and absence of boron. In order to retain the appropriate electrical conductivity $\left(0.03 \mathrm{dS}^{*} \mathrm{~cm}^{-1}\right)$ in the irrigation a second pass RO membrane is avoided, and instead boron specific ion exchange resin is utilized. Table 3 and 4 summarizes the different post-treatment processes required, along with four different process details.

Table 3. Post Treatment processes required for various applications [18] [Copyright (C 1998-2019 Lenntech B.V. All rights reserved].

\begin{tabular}{|c|c|c|c|}
\hline Process & Drinking-Water & Irrigation Water & Process Water \\
\hline Removal of $\mathrm{NaCl}$ & Second pass RO & - & Second pass RO \\
\hline Re-mineralization & $\begin{array}{l}\text { Calcium and Magnesium } \\
\text { addition }\end{array}$ & $\begin{array}{l}\text { Calcium and Magnesium } \\
\text { addition }\end{array}$ & - \\
\hline $\begin{array}{l}\text { Neutralization } \quad(\mathrm{pH} \\
=7)\end{array}$ & $\mathrm{NaOH} / \mathrm{HCl}$ injection & $\mathrm{NaOH} / \mathrm{HCl}$ injection & $\begin{array}{l}\mathrm{NaOH} / \mathrm{HCl} \\
\text { injection }\end{array}$ \\
\hline Boron Removal & $\mathrm{NaOH}+$ second pass $\mathrm{RO}$ & $\begin{array}{l}\text { Boron specific ion exchange } \\
\text { resin }\end{array}$ & - \\
\hline Disinfection & Required & Not Required & Not Required \\
\hline
\end{tabular}

Table 4. Post Treatment process details [19] [Copyright () 1998-2019 Lenntech B.V. All rights reserved].

\begin{tabular}{|c|c|c|c|}
\hline $\begin{array}{l}\text { Remineralization } \\
\text { Process }\end{array}$ & Description & Minerals & $\begin{array}{l}\text { Water } \\
\text { Quality }\end{array}$ \\
\hline 1 & $\begin{array}{l}\text { Blending with } 1 \% \text { clarified } \\
\text { seawater }+\mathrm{pH} \text { neutralization }\end{array}$ & $\begin{array}{l}15 \mathrm{mgL}^{-1} \text { Magnesium }+5 \mathrm{mgL}^{-1} \text { Calcium } \\
+125 \mathrm{mgL}^{-1} \quad \text { Sodium }+220 \mathrm{mgL}^{-1} \\
\text { Chlorine }+25 \mathrm{mgL}^{-1} \text { sulphate salts } \\
\text { pH 7-7.5 }\end{array}$ & Medium \\
\hline 2 & 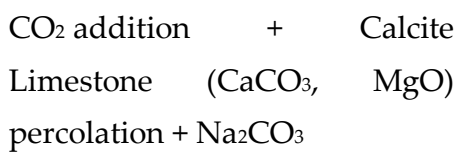 & $\begin{array}{l}80 \mathrm{mgL}^{-1} \mathrm{CaCO}_{3} \\
\mathrm{pH} 7-7.5\end{array}$ & Good \\
\hline 3 & $\begin{array}{l}\mathrm{CO}_{2} \text { addition }+ \\
\text { Limestone }\left(\mathrm{CaCO}_{3}, \quad \mathrm{MgCO}_{3}\right) \\
\text { percolation }+\mathrm{Na}_{2} \mathrm{CO}_{3}\end{array}$ & $\begin{array}{l}80 \mathrm{mgL}^{-1} \mathrm{CaCO}_{3}+\mathrm{MgCO}_{3} \\
\text { pH } 7-7.5\end{array}$ & $\begin{array}{l}\text { Very } \\
\text { Good }\end{array}$ \\
\hline 4 & $\mathrm{CaCl}_{2}+\mathrm{NaHCO}_{3}$ addition & $\begin{array}{l}100 \mathrm{mgL}^{-1} \mathrm{CaCO}_{3}+100 \mathrm{mgL}^{-1} \text { Sodium }+ \\
50 \mathrm{mgL}^{-1} \text { Chlorine } \\
\text { pH } 7 \text { - } 7.5\end{array}$ & Medium \\
\hline
\end{tabular}

\section{Role of nanofluids in energy-efficient desalination}

\subsection{Basics of Nanofluids}

Nanotechnology finds application in the membrane as well as thermal desalination. In the scope of work for this paper, only nanotechnology application for thermal desalination is considered, as nanomembranes at present are far from the commercial production and application phase [20]. For thermal desalination, the thermal properties of the heat transfer fluid are crucial. Since the industrial revolution, water and some improved heat transfer fluids have been developed and 
commercialized. However, there are some demerits associated with traditional heat transfer fluids. Nanofluids, on the other hand, provide a basis for efficient heat transfer. Nanofluids are an engineered suspension of nanoparticles in base fluids (inorganic or organic) with the support of surfactants. In the past few years, different nanofluids have been prepared, characterized and tested for heat transfer applications. The experiments have shown an enhancement in the thermal properties of nanofluids as compared with the base fluids. To consider some examples, the specific heat capacity of nanofluids (prepared by suspending nanoparticles in molten salts base fluids) have increased by almost $25-28 \%$ [21-22]. The enhancement of $25 \%$ in specific heat capacity of the nanofluids as compared with base fluids will lead to a $20 \%$ reduction in the thermal energy storage (TES) salt inventory and thus TES cost reduction. The research carried out with $50 \mathrm{MW}$ solar thermal plant with 15 hours TES exhibited 9\% reduction in TES cost along with $0.9 \%$ reduction in total solar thermal plant cost (due to the reduced size of systems) in addition to the mitigation in prices of TES salt [22]. There is a range of studies which have exhibited that nanofluids possess higher thermal properties than traditional heat transfer fluids, which allow more efficient heat transfer for process heat production and other applications. The process heat from a wide range of sources is commonly utilized for thermal desalination and other applications within industry. The improvement in physical and thermal properties of the resultant nanofluid depends on the nature of nanoparticles, the base fluid and surfactant utilized. Generally, the viscosity of the nanofluid is higher than the base fluid for water and other liquid solvents. However, nanoparticles reduce the viscosity of the fluids when suspended in molten salt solutions. Hence, the selection of the nanofluid varies from one application to the other. Zhang et al. [23] and Kasaeian et al. [24] discusses the details on different mechanisms and role of different parameters on nanofluids effect on productivity enhancement in specific applications. Zhang et al. [23] focused on the effect of nanofluids on $\mathrm{CO}_{2}$ absorption and overall effect on the carbon capture industry. The paper discusses various nanofluid manufacturing processes along with enhancement mechanisms which include "Grazing effect", "hydrodynamic effect" and "inhibition of bubble coalescence". Grazing effect defines the absorption rate of gas in liquids which enhances with the presence of solid particles in the gas-liquid-solid three-phase system. Hydrodynamic effect defines the gas-liquid boundary layer effects. Nanoparticles present around bubbles leads to a thinner effective layer as the nanoparticles break the diffusion layer. The thinner boundary layer promotes gas diffusion into the liquid film, which ultimately increases turbulence and mass transfer coefficient. However, due to factors like surface tension, surface forces and hydrodynamic effect, the thin layer may get rupture which leads to bubble coalescence which can be inhibited by the mixed liquid phase. The enhancement mechanism is resultant of these three fundamental mechanisms. In the $\mathrm{CO}_{2}$ absorption process, grazing effect and hydrodynamic effect play a vital role [23]. Furthermore, the effect of various other factors such as temperature, particle size and concentration of nanofluid are also discussed. Kasaeian et al. [24] discussed the role of nanofluids in heat transfer in porous media. The paper reviewed the effect of nanofluids and porous media on heat transfer. The paper concluded that both nanofluids and porous media supports higher heat transfer rates as nanofluids possess higher thermal conductivity, whereas porous media provides enhanced surface area, which leads to higher heat transfer rates. Furthermore, the hypothesis of heat transfer enhancement in porous media was tested with the most popular models Buongiorno and Tiwari and Das. It has been reported that nanoparticles usually enhance fundamental thermal properties of the base fluid, which are essential in reducing the size of the system or producing more output for a similar size of the system. For integrated sustainable thermal desalination systems, the role of energy storage, overall heat transfer and economies of scale in products, is vital.

\subsection{Application of Nanofluids for thermal desalination}

The fundamental principle of thermal water desalination is similar to the concept of rain formation. The process of thermal distillation strips seawater with heavy metals along with other impurities. The produced water is as clean as pure rainwater. Thermal energy can be supplied from different sources, including solar thermal technologies. Nanofluids allow efficient heat transfer, and 
apart from studies in nanofluids thermal properties enhancement for CSP power generation, researchers also considered the application of nanofluids for efficient thermal desalination processes. Sharshir et al. [25] experimented with three different solar stills and utilized nanofluids to improve the performance of solar stills. The micro flakes concentrations in nanofluids were ranged from $0.125 \%$ to $2 \%$ with basin depths in the range of 0.25 to $5 \mathrm{~cm}$. The average particle size for the micro-flakes of graphite and copper oxide was 1.2-1.3 micrometre and one micrometre, respectively. The use of graphite and copper oxide microparticles with glass-cooling enhanced productivity by $53.95 \%$ and $44.91 \%$ respectively, for the solar stills, as compared with standard models. The authors aspired to achieve productivity enhancements through varying the concentration of nanofluids, in which promising results were obtained and are reported in Figure 5.

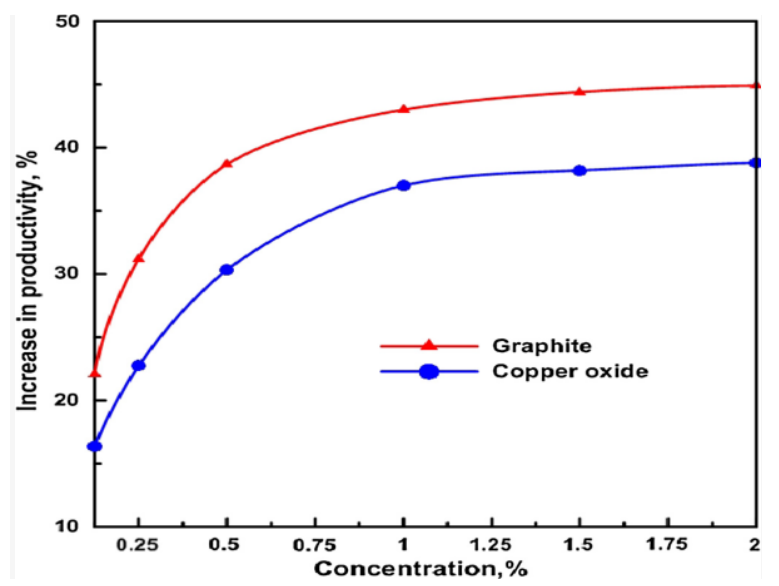

Figure 5. Increment in solar stills productivity with varying nanofluid concentrations [25].

From, figure 5, it can be depicted that the weight concentration of the micro-flakes affects productivity proportionately. Moreover, the graphite-based nanofluid solution enhances productivity more than the copper oxide-based solution because the thermal conductivity of graphite is higher than copper oxide. Higher thermal conductivity leads to higher absorption of solar radiation and hence a higher amount of thermal energy is provided for desalination. Furthermore, the figure 5 can be divided in three zones i.e. $0.125 \%$ to $1 \% ; 1 \%$ to $1.5 \%$ and $1.5 \%$ to $2 \%$. In the first zone, water productivity enhancement is rapid with both the solutions, whereas in the second zone, the pace of growth is low. However, the third zone shows no remarkable growth in productivity. Hence, it can be ratiocinated that beyond the optimum weight concentration, there is no significant growth in productivity and for all practical applications this optimum concentration should be considered as the ideal point which is $1 \%$ in this case [25]. Chen et al. [26] prepared various concentrations of nanofluids by dispersing $\mathrm{Fe}_{3} \mathrm{O}_{4}$ modified MWCNTs nanoparticles in saline water. MWCNTs with 8-15 nm diameter and 95\% purity were modified to impart magnetic properties with inspiration from the work of Manlin Wang and Lang Shao et al. [27-28]. The nanofluids were prepared with different concentrations ranging from 0 to $0.04 \mathrm{wt} \%$ by using a two-step method. Moreover, the stability of nanofluids was analyzed by measuring zeta-potential and solutions were to be of excellent stability in pure water which was degraded with salt loading in the water. At salt concentrations of 5000 ppm in water, the zeta potential value was significantly poor. Some specialized surfactants were used to achieve the moderate stability of nanofluids in saline water. Furthermore, the optical properties of magnetic MWCNTs were analyzed, and it was reported that prepared nanofluids could successfully ameliorate the utilization rate of solar energy to provide more heat energy for saline water evaporation. The author observed $100 \%$ absorption for solar energy when the fluid thickness increased beyond $1 \mathrm{~cm}$. This absorption 
was observed for $0.04 \mathrm{wt} \%$ nanofluid. Furthermore, the evaporation efficiency was found to be enhanced with increased nanofluid concentration. For $0 \mathrm{wt} \%$, the evaporation efficiency was $24.91 \%$, and for $0.04 \mathrm{wt} \%$, it was discovered to be $76.65 \%$. Kabeel et al. [29] studied the effect of a nanofluid-based solar collector on the flashing desalination technique (Similar to MSF). The authors tested the model for various operational modes, including functional parameters as well as different weather conditions. Copper nanoparticles were used for modelling the system, and it was found that the system was highly efficient but not economically viable as the system in the test study was a small-scale unit. Some improvements, such as using a higher collector area and the use of appropriate volume fractions of nanoparticles for mitigating the costs were suggested. Based on the mathematical model developed, the study showed that the solar water heater collecting area is considered a significant factor for reducing the water production cost. Also, the produced water costs decrease with increasing the collecting area of the solar water heater. The volume fractions of nanoparticles in solar collector working fluid have a significant impact on increasing the freshwater production and decreasing cost. Moreover, Chen et al. [30] carried out an experimental investigation of silicon carbide nanofluids based on seawater for solar distillation. The experiment reported an enhancement in thermal conductivity by $5.2 \%$ for saltwater based nanofluid. Since the salt concentration in water negatively affects the stability and thermal conductivity of the nanofluid and the optimum concentration is necessary. The team reported a decrease in thermal conductivity with concentrations higher than 5000 PPM. Also, the zeta potential values for the samples (stability) reduced considerably for higher concentrations. The thermal conductivity reduced by almost $6 \%$ at the same temperature of $10{ }^{\circ} \mathrm{C}$ for concentrations at 50000 PPM as compared with 0 PPM. The research concluded that at lower salt concentrations of TDS of the seawater, SiC nanofluids showed excellent stability and higher thermal conductivity, which confirms the feasibility of the nanofluid for solar desalination. Kumar et al. [31] reviewed the performance of heat carrier nanofluids for solar still applications and concluded that the output of solar still initially increases with the particle concentration in the nanofluid, but it deteriorates at higher particle concentrations due to the higher viscosity and increase in pressure drop in the system. A brief review of various nanofluids application in solar stills is outlined in table 5 .

Table 5. Review of nanofluids in solar still [31].

\begin{tabular}{|c|c|c|c|c|c|}
\hline $\begin{array}{l}\text { Base } \\
\text { Fluid }\end{array}$ & Nanofluid & $\begin{array}{c}\text { Nanoparticles } \\
\text { Thermal } \\
\text { conductivity } \\
\left(\mathrm{W}^{*}(\mathrm{mK})^{-1}\right) \\
\end{array}$ & $\begin{array}{c}\text { Volume } \\
\text { concentration } \\
(\%)\end{array}$ & Observation & Ref. \\
\hline Water & $\mathrm{Al}_{2} \mathrm{O}_{3}$ & 46 & $0.04,0.08,0.12$ & $\begin{array}{c}\text { For } 0.12 \% \text {, the productivity } \\
\text { enhanced by } 16.83 \%\end{array}$ & 32 \\
\hline Water & $\begin{array}{l}\mathrm{CuO} \\
\mathrm{Al}_{2} \mathrm{O}_{3}\end{array}$ & $\begin{array}{c}17.6 \\
46\end{array}$ & $\begin{array}{l}0.02 \\
0.02\end{array}$ & $\begin{array}{l}\text { Efficiency of solar still increased by } \\
84.16 \% \text { for } \mathrm{CuO} \text { and } 73.85 \% \text { for } \\
\qquad \mathrm{Al}_{2} \mathrm{O}_{3}\end{array}$ & 33 \\
\hline \multirow[t]{2}{*}{ Water } & $\begin{array}{l}\text { - } \mathrm{Al}_{2} \mathrm{O}_{3} \\
\text { - } \mathrm{ZnO} \\
\text { - } \mathrm{Fe}_{2} \mathrm{O}_{3} \\
\text { - } \mathrm{SnO}_{2}\end{array}$ & $\begin{array}{c}46 \\
29 \\
6 \\
1.34-1.38\end{array}$ & $\begin{array}{l}0.05-0.1 \\
0.05-0.1 \\
0.05-0.1 \\
0.05-0.1\end{array}$ & $\begin{array}{l}29.95 \% \\
12.67 \% \\
------- \\
18.63 \%\end{array}$ & 34 \\
\hline & & & & Productivity enhancement & \\
\hline
\end{tabular}




\begin{tabular}{|c|c|c|c|c|c|}
\hline Water & $\mathrm{CuO}$ & 17.6 & 0.12 & $22.5 \%$ in the total productivity & 35 \\
\hline $\begin{array}{c}\text { Mix with } \\
\text { black } \\
\text { paint }\end{array}$ & $\mathrm{CuO}_{2}$ & 76.5 & $10-40$ & $25 \%$ increment in productivity & 36 \\
\hline $\begin{array}{l}\text { Mixed } \\
\text { with } \\
\text { black } \\
\text { paint }\end{array}$ & $\mathrm{Al}_{2} \mathrm{O}_{3}$ & 46 & ------ & $38.09 \%$ increment in productivity & 37 \\
\hline Water & $\begin{array}{c}\text { Graphite } \\
\text { Flakes } \\
\mathrm{CuO}\end{array}$ & $\begin{array}{l}129 \\
17.6\end{array}$ & $0.125-2$ & $\begin{array}{l}\text { Productivity increased by } 53.95 \% \\
\text { for graphite flakes while } 44.91 \% \\
\text { increment was observed for } \mathrm{CuO} \\
\text { nanofluids }\end{array}$ & 38 \\
\hline
\end{tabular}

This section focused on nanofluids applications for desalination systems. As discussed, nanofluids provide a feasible basis for the development of efficient desalination systems due to their enhanced thermal properties. Desalination is an energy-intensive process, and hence, it is vital to power the desalination systems with environment-friendly technologies. Nanofluids support a reduction in energy consumption initially, which has been termed as "NegaWatt. The NegaWatt is defined as a theoretical unit of power which is saved due to energy conservation or efficiency increment. This term was coined by Amory Lovins - chief scientist Rocky Mountain Institute in 1985 through the article "Saving Gigabucks with Negawatts". Hence, NegaWatt and Megawatt generated through sustainable processes will support the development of sustainable desalination, if other environmental issues associated with desalination are solved. The problems of energy consumption and environmental damage are discussed in further sections.

\section{Energy consumption, economics and environment: Analysis of renewable energy-based desalination}

Despite the significant achievements in decreasing the overall energy consumption, desalination remains an energy-intensive process. A technical paper from the "World Bank Group" outlines energy consumption data for commercial desalination plants established globally. The economics of desalination projects is directly linked with the energy consumption in the desalination projects. The report from "World Bank Group" indicates that almost $66 \%$ and $41 \%$ of the total operating expense of thermal and reverse osmosis desalination, respectively, is dedicated to energy consumption [39]. Hence, the lower the cost of energy or lower the energy consumption will directly affect the final price of the desalinated water. The other factors which play deciding role in the final cost of desalinated water include salinity of the raw seawater along with project financing, construction costs, discharge of concentrated brine, chemicals requirement for the treatment of raw seawater and others. Figure 6 indicates the LCOW (Levelized cost of water) prices for various technologies. The electricity cost assumed for the calculations is $0.05 \mathrm{USD}^{*}(\mathrm{kWh})^{-1}$ and crude oil price 60 USD per barrel for thermal energy calculations [39]. Powering desalination plants with sustainable technologies is mandatory to obtain the objective of sustainable desalination processes. Since at present most of the energy required for powering desalination processes is sourced from fossil-fired power plants, the $\mathrm{CO}_{2}$ production along with other emissions of sulphur and nitrogen are considered pollutants (potential greenhouse gases (GHGs) which contribute significantly to global warming and global climate change) and which are harmful to the environment. Nanotechnology applications will either reduce the specific energy consumption for membrane-based desalination or will transfer heat at a higher rate, which will reduce the requirement of energy production beforehand, and hence lesser emissions for fossil powered desalination projects along with a reduction in cost for final desalinated water. Furthermore, nanotechnology allows a possible development of independent renewable energy-based desalination projects, thereby eliminating the probability of GHG emissions. A detailed emissions analysis is given in table 6 . 


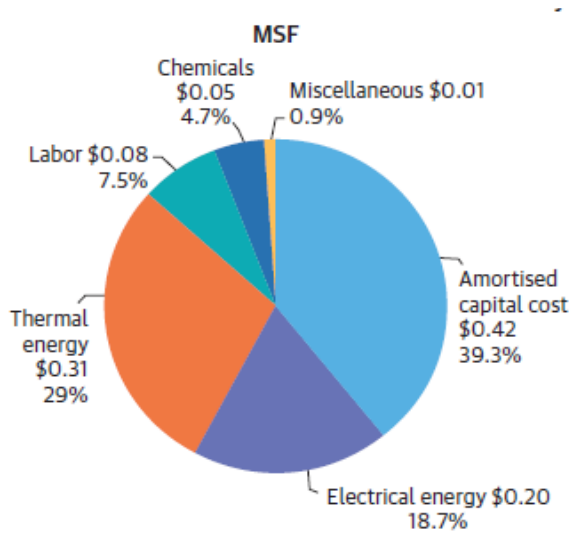

$\$ 1.07 / \mathrm{m}^{3}$

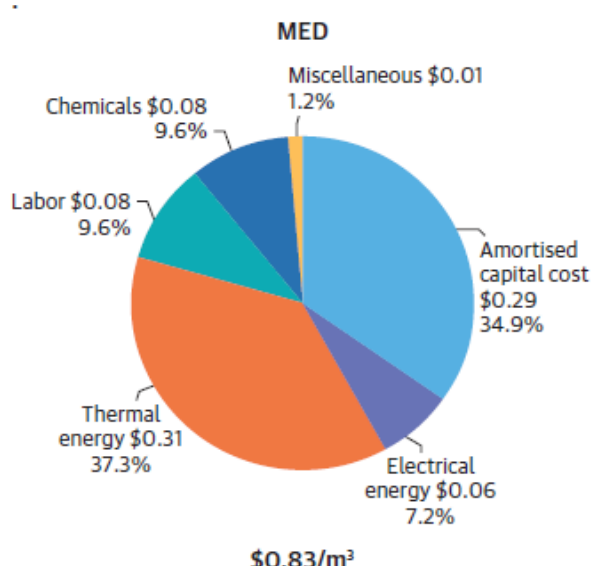

$\$ 0.83 / \mathrm{m}^{3}$

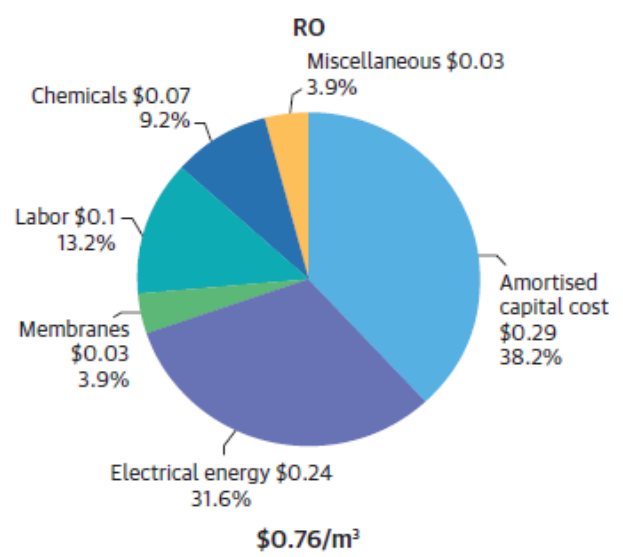

Figure 6. Cost component of the thermal desalination and reverse osmosis technologies [39]. [@ 2019 International Bank for Reconstruction and Development / The World Bank].

Table 6. Pollutants emission levels for powering MSF and RO plants [40].

\begin{tabular}{|c|c|c|c|c|c|c|c|c|c|}
\hline \multirow[t]{2}{*}{ S.No. } & \multirow{2}{*}{$\begin{array}{l}\text { Type of Power } \\
\text { Plants }\end{array}$} & \multicolumn{4}{|c|}{ MSF (Million $\mathbf{t}^{*} \mathrm{yr}^{-1}$ ) } & \multicolumn{4}{|c|}{ RO (Million $\mathbf{t}^{*} \mathrm{yr}^{-1}$ ) } \\
\hline & & $\mathrm{CO}_{2}$ & $\mathrm{SO}_{\mathrm{x}}$ & $\mathrm{NO}_{x}$ & Particles & $\mathrm{CO}_{2}$ & $\mathrm{SO}_{\mathrm{x}}$ & $\mathrm{NO}_{x}$ & Particles \\
\hline 1 & Coal Fired & 264.5 & 0.33 & 0.54 & 0.04 & 32.2 & 0.04 & 0.07 & 0.005 \\
\hline 2 & Oil Fired & 216.2 & 1.31 & 0.30 & 0.03 & 25.7 & 0.16 & 0.04 & 0.003 \\
\hline 3 & Gas Turbine & 141.6 & 0.01 & 0.23 & 0.01 & 12.9 & 0.001 & 0.02 & 0.001 \\
\hline
\end{tabular}

The use of renewable energy for the desalination process offers multiple benefits ranging from the mitigation of greenhouse gas emissions, lower operational and maintenance costs, ease of use in remote areas and high reliability in the long term.

Brine discharge mitigation

Apart from the GHG (Green House Gas) emissions, the other hurdle in sustainable desalination projects is the concentrated brine discharge to the sea. The concentrated brine from desalination plants poses a severe threat to the marine ecosystem. There are several brine management processes including ZLD (Zero Liquid Discharge -where 100\% water recovery is possible from brine), fertilizers production, mixing brine with sewage wastewater, utilizing brine for salt production through solar ponds, application in brine tolerable crop cultivation and deep well injection [41-43]. However, each of these processes has merits and demerits associated with them, and the final selection of the technology depends on the circumstances and priorities of the project developers. Microplastic pollution

Plastic pieces with less than five millimeters size are considered as "Microplastics", and these small pieces are dumped in oceans via various water streams. Microplastics are a burgeoning threat 
to the marine ecosystem as well as to humans through the food chain. The microplastics get into the human food chain via common salt, drinking water, fish and other seafood consumed by humans. At present, some technologies have been developed to deal with the mess created by plastics in the water bodies. Some of the techniques and projects include "The Great Bubble Barrier" and "Ocean Cleanup". "The Great Bubble Barrier" technique makes use of air bubble barrier at the bottom of the water body which ultimately pushes the waste to the surface of the water where it gets screened away from the water for reprocessing [44]. The Ocean cleanup project designed in TU Delft is focused on plastic cleanup in the oceans unlike "Great Bubble Barrier" which targets freshwater bodies like rivers, canals and channels [45]. Both of these techniques are suitable to remove a large chunk of plastics from water bodies. However, none of these techniques commented on the microplastics collection. In order to protect future desalination projects from microparticles pollution, pre-treatment technologies such as nanofiltration, ultrafiltration or microfiltration with pore sizes in the range of 0.001 microns, 0.01 microns and 0.1 microns, respectively, can be deployed to ensure complete elimination of the microparticles from the drinking water [46].

The desalination process is an energy-intensive process in which fossil fuel-driven power plants have traditionally powered MSF, MED and RO plants. Renewable energy desalination has gained acceptance due to the decrease in the Levelized Cost of electricity for renewable systems and increasing environmental awareness [47]. At present, renewable energy coupled desalination processes account for less than $1 \%$ of the total globally installed desalination capacity in which, PV-RO (Photovoltaics combined with RO) presents the largest share [47]. In terms of renewable energy-based desalination systems, Bitar et al. [47] compared nuclear and solar-powered desalination systems. The study concluded that solar PV panels, coupled with reverse osmosis, are the highest performing systems in terms of economics. In the analysis provided the produced water cost computed USD 0.85 per cubic meter for solar PV with RO; however, the price was marginally higher in the case where nuclear energy was utilized to power the RO. However, MED and MSF demonstrated an inverse relationship. MED and MSF coupled with nuclear resulted in a cost of water production of 1.22 and 2 USD per cubic meter, respectively which is lower than the cost of water in the cases where both these systems are powered by a CSP power tower and parabolic trough collectors.

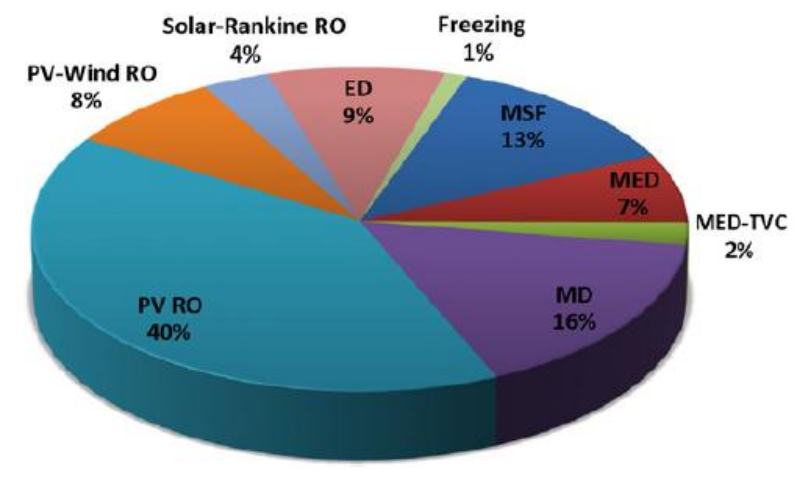

Figure 7. Share of renewable desalination technologies installed worldwide [50-51].

Furthermore, Jung et al. [48] studied the effects of a small-scale nuclear heat only plant for desalination in the UAE. The study included a comparison between LNPP (Large-sized Nuclear Power Plant) and SHNP (small-sized nuclear heat-only plant in which only heat energy is utilized in the form of steam from nuclear plants) coupled with MED-TVC desalination system. The study concluded that SNHP, coupled with MED-TVC process, resulted in the lowest water cost amongst the different combinations investigated in the study. The price of SNHP - MED-TVC was 1.142 USD per cubic meter [48], which is lower than the LNPP-MED-TVC for which the LWC was 1.22 USD per cubic meter. Although powering desalination plants with nuclear energy will contribute towards a lifecycle reduction in GHG emissions, there are concerns regarding the potential for radiation leaks. Figure 7 illustrates the share (\%) of various renewable-based desalination systems 
installed globally. The PV and RO combination system is the most utilized ( $40 \%$ of the total global renewable desalination installed capacity) [50-51]. Incidentally, the coupled PV and RO systems result in the lowest reported LWC.

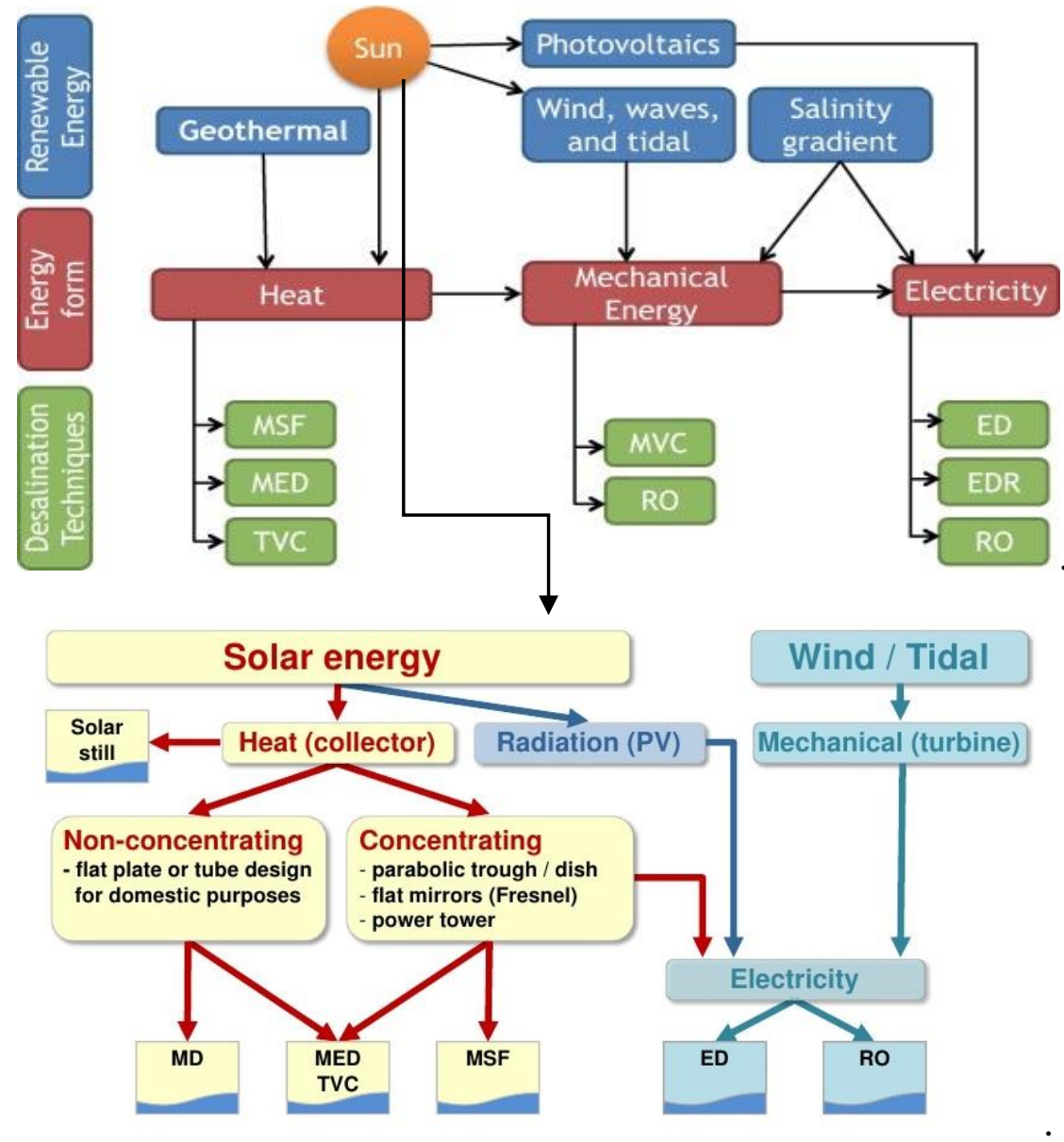

Figure 8. Renewable energy integration with various desalination technologies [53].

Frantz et al. [49] analyzed the potential collaboration between MED and a solar tower plant and reported that by increasing operating temperature for MED operations from $65^{\circ} \mathrm{C}$ to $90{ }^{\circ} \mathrm{C}$, double water output could be achieved by sacrificing $11 \%$ power generation potential. Furthermore, the water output can be increased by $50 \%$ if the heat transfer surface area is enhanced by $30 \%$. Casimiro et al. [52] analyzed the integrated MED with CSP system and reported that a MED/SWCC (Seawater Cooling Circuit) process coupled with CSP co-generation technology results in an economically competitive water cost. The electrical output performance of this system was measured as only $5 \%$ lower than conventional CSP coupled with wet cooling. However, the CSP and MED/SWCC system produced freshwater, which was not the case with the traditional system. PV and wind-based desalination technologies are best suited for $\mathrm{RO}$, whereas geothermal and nuclear can be utilized both for RO as well as thermal desalination. The choice of technique depends on location and factors of salinity and availability of renewable energy resources. Figure 8 outlines the possibility of integration for renewable energies with various desalination technologies and commercial status of renewable energy-based desalination technologies. Several renewable desalination technologies integration has been discussed. The sun is the source of different renewable sources on earth including wind, solar energy, waves and tidal energy (gravitational forces exerted by sun, moon and rotation of earth generate tidal energy). Apart from the sun, geothermal energy is considered part of renewable desalination. However, geothermal energy is limited to some regions of the globe and not available ubiquitously. All these resources either produce fresh water through process heat, mechanical arrangements or electricity. Depending on the source of renewable energy, different 
desalination technologies are utilized such as MSF, MED and TVC desalination technologies utilize process heat from solar, geothermal or any other source whereas MVC and RO utilize mechanical energy from wind, waves and tides. Similarly, RO, EDR and ED are powered by electricity which can be generated from photovoltaics (solar energy), mechanical or heat energy. The other form of direct solar energy utilization apart from photovoltaics is solar thermal or concentrated solar power along with non-concentrating energy. Heat collectors are utilized for both of these processes. Typical heat collectors for non-concentrating or low concentrating solar energy technologies are flat or evacuated tube collectors with an operating temperature of maximum up to $200{ }^{\circ} \mathrm{C}$. High concentration solar collectors such as Parabolic Trough, Linear Fresnel, Power Tower and Sterling dish operate at temperatures as high as $1000{ }^{\circ} \mathrm{C}$. As the temperature requirements for thermal desalination are not more than $120^{\circ} \mathrm{C}$, non-concentrating technologies can be utilized. However, in order to develop standalone desalination system, it requires heat energy round the clock which leads to the requirement of thermal storage, and hence high temperature solar thermal collectors play a crucial role in the development of independent renewable desalination systems. Moreover, the efficiency of the high temperature collectors is almost double that of the low-temperature flat plate collectors. The high temperature collectors allow the development of integrated desalination systems where electricity generated from high temperature steam either can be dispatched in grid or can be utilized for powering RO or other membrane-based desalination systems along with desalinated water production from the waste heat of the turbine by utilizing thermal desalination systems. Some of the recent developments are discussed further.

Although the MSF process is more cost-intensive and is rarely used for brackish water, it often possesses larger production capabilities. $\mathrm{RO}$ which can be applied to both brackish water and seawater is more flexible and is cheaper. Hassabou et al. [54] reported that powering MSF and RO plants with concentrated solar thermal (with storage) will increase the cost marginally. However, the benefits marginalize the cost as the technology is sustainable, and the cost factors can also vary for different regions of the world. Furthermore, layering the heat transfer pipes in the concentrated solar power desalination unit can increase the efficiency of the plant by 30\% [55]. Alternatively, solar-thermal coupled with thermal desalination technologies are best suited for the MENA region as CSP-MED is more energy-efficient than CSP-RO due to high salinity gradient (German Aerospace Centre, 2007). The salinity gradient is considerably higher in the Arabian Gulf compared to other locations. Furthermore, it has been reported that the salinity of the Arabian Gulf has increased by 1.5 times in the past 20 years [56]. Similar findings had also been reported by the UAE ministry of environment and water in 2009. As per the records, the historical salinity (30 years ago) in Gulf was in the range of 35,000 to 37,000 PPM, whereas the salinity measured in 1999 was 42,000 PPM, which further increased to 56,000 PPM in the year 2009. The average increment rate was $3.3 \%$ every year [57]. As such, RO membranes may face challenges related to fouling and coagulation due to decreasing water quality. Moreover, RO membranes cannot block certain chemical contaminants, boron, chlorine, bacteria and materials with micron sizes smaller in size than that of the pores. Furthermore, Li et al. [58] from the Harvard Kennedy School studied the effect of ocean energy for desalination. The ocean energy primarily includes OTEC (Ocean thermal energy conversion), Ocean mechanical energy (OME) and Ocean chemical energy (OCE). OTEC works on the temperature gradient between the upper surfaces and lower surfaces of ocean water, whereas the OCE operates on the salinity gradient of two liquids. Some of the common OCE techniques include Forward Osmosis, Pressure Retarded Osmosis and Reverse Electrodialysis. Wave energy, ocean currents and tides constitutes the OME technologies. These technologies can be utilized for small and medium scale operations and can not only mitigate GHG (Green House Gas) emissions but can also curb negative impacts of brine discharge on the marine ecosystem as OCE utilizes concentrated brine for power production. The MENA region can expect future development in coupling renewable energy with desalination as it accounts for approximately $38 \%$ of global desalination capacity, while water demand is expected to increase by up to 13.3 billion cubic meters by 2030 [59]. Coupled with the limited supply of groundwater resources in the region, the desalination capacity is expected to increase to 110 million cubic meters per day, with a threefold increase in the energy demand as 
compared with 2007 [59]. Currently, Saudi Arabia operates the largest capacity of desalination plants in the region in which 1.5 million barrels of oil annually is utilized to meet approximately $50 \%$ of countries water demand until 2010 [59]. Saudi Arabia has recently started construction of the world's largest Ultra High Concentration Photovoltaic- membrane-based desalination plant in collaboration with IBM with a total capacity of 30,000 cubic meters per day [59]. Alkaisi et al. [60] reviewed integrated renewable energy-based desalination systems and concluded that amongst all the renewable sources, solar energy is the most promising renewable energy source as compared with other peer technologies along with fossil fuel-powered desalination projects. Some prominent researches have been carried out for the integration of solar thermal technologies with desalination. Qiblawey et al. [61] reviewed the solar technologies for desalination and reported similar findings, as discussed previously. Dongare et al. [62] focused on the development of improving the efficiency of solar thermal distillation through the redistribution of solar radiation over small focus elements. Furthermore, Hoffman et al. [63] published a case study from Namibia on integrating desalination with CSP technologies. The research concluded if the air-cooled condenser is replaced with a MED system in the central receiver, then, the thermal efficiency of the process will reduce to some extent, but it can be managed through the sales of the freshwater produced in the process. Although the cost of integrated renewable desalination is higher, except PV-RO combination, there lies significant ground for the development of cost-competitive RED (Renewable energy desalination) technologies. Now, keeping these advancements into consideration, the objective of the development of a cost-competitive sustainable desalination technology can be achieved by solving the problems of environmental issues associated with desalination processes as discussed along with powering the projects with renewable energy with nanofluids as heat transfer fluids. This hypothesis is further discussed in the following section.

\section{Opportunity to develop renewable energy powered cost-competitive sustainable desalination}

Nanomembranes and nanofluids based thermal desalination are the two advances discussed in present times, as alternatives to the traditional desalination processes and which can support the objectives of the development of cost-effective and environment-friendly desalination processes. However, nanomembranes at present are at the nascent stage of development and require additional research to tackle the issues (toxicity, economics, large scale production and more) associated with nanomembranes before commercializing them at an industrial scale [20]. However, since nanofluids do not come into contact with the seawater, and no significant changes are required in the present systems, they can play a vital role in thermal desalination systems which are integrated with renewable energy sources. Moreover, from the previous discussion and from figure 6, it can be deduced that MED desalination is competitive with reverse osmosis technology. Hence, on this basis, a range of technologies has been developed for improving the efficiency of the MED systems. One of these technologies is MEDAD (Multi-Effect Distillation with an Adsorption Desorption cycle) which improves the water output for the same amount of energy input through the addition of an adsorption-desorption system. The economic analysis carried out by MEDAD developers showed that a $36.56 \%$ reduction in LCOW is possible through MEDAD as compared with MED technology [64-67]. With this reduction, figure 6, will reduce the final water price for MED to 0.527 USD per cubic meter, which is significantly lower than the reverse osmosis technology-based water price. The use of MEDAD has an additional advantage in which it generates potable water at low temperatures, which minimises fouling and scaling. Furthermore, Mabrouk et al. [68-69] developed a novel design of MED system, which obtains a higher GOR by reducing the effective evaporator surface area, i.e. enhanced heat transfer through the evaporator. This system is expected to deliver higher water output against a reduced footprint (fewer emissions) and reduced energy embedded in producing components of MED systems. The pilot plant of the novel MED system with a capacity of 24 tons per day is in the construction and testing phase. Moreover, the team studied the techno-economic aspects of the MSF-MED hybrid desalination process and reported that MSF-MED system yields $21 \%$ lower LCOW as compared with MED-TVC and 32\% lower than MSF-Brine Recycling. Also, the pumping power reduced for MSF-MED by $58 \%$ and $16 \%$ as compared with 
MSF-Recycling Brine and MED-TVC, respectively [69]. The team concluded that MSF-MED is the best thermal technology for the GCC region. Thus, it can be concluded that MED provides a basis for the development of competitive desalination technology. Furthermore, Jani et al. [70] reviewed several research articles and concluded that nanofluids enhanced heat transfer from the absorber plate. Nanofluids have improved thermo-physical properties such as density, thermal conductivity and more, which increased the heat transfer rate. Hussein et al. [71] and Singh et al. [72] concluded that nanofluids play a crucial role for efficient heat transfer and power generation which is a significant part of desalination and utilizing nanofluid based heat transfer will reduce water production costs. Sharon et al. [73] and Reif et al. [74] reported that while traditional solar systems were designed for electricity production, modified systems with advanced heat transfer characteristics are necessary, in order to satisfy present energy and water needs globally. Furthermore, traditional solar thermal technologies are mainly utilized for power generation with the possibility of thermal desalination integration in some cases. However, the newly developed PV-Thermal (Photovoltaic's - Thermal) with TES (Thermal Energy Storage) can produce electricity as well as hot water up to $200{ }^{\circ} \mathrm{C}$. Hassabou et al. [75] developed an innovative hybrid PV - Thermal non-evacuated solar collector which operates on GHI (Global Horizontal Irradiance) and can generate electricity and hot water round the clock, effectively. The system increases solar panels efficiency by reducing the operating temperature along with utilizing heat to produce hot water which can be stored in TES tanks. The system will allow the development of hybrid membrane-thermal desalination plant operating entirely on solar energy.

In continuation of the above-discussed desalination technologies, several types of research carried out for the development of advanced technologies, which can deal with problems of existing commercial systems. Some of the issues associated with existing membrane and thermal desalination systems are higher energy consumption per cubic meter of permeate produced, membrane fouling, lower GOR/PR (Gain Output ratio or Performance Ratio) for thermal desalination systems (due to lower permeate), substantial environmental damage through contaminated toxic brine discharge and significant share in GHG emissions. The research and development carried out in recent years focussed on increasing permeate quantity through design changes, utilizing nanomaterials for desalination specific membranes and treatment of toxic concentrated brine. The latest developments are discussed in detail further. Al-Karaghouli et al. [76] studied the solar and wind opportunities for desalination in the Arab region and presented an economic analysis for final LWOC of water by using solar (PV and solar thermal) and wind energy technologies. The systems studied included solar/MSF, solar-wind/RO and solar/MED. The research concluded that these systems powered with either solar or wind energy could compete with the conventional energy-powered desalination systems. The LWOC for renewables-based water production was significantly higher back in 2008. However, today, the cost of solar energy has decreased by approximately a magnitude of 10 over the last decade. El-Ghonemy et al. [77] studied sustainable water desalination technologies in which a range of options have been considered. The primary outcome of the study was the application of solar CSP (Concentrated Solar Power) for desalination plants (Either RO or thermal desalination). Unlike PV and wind-powered desalination plants, CSP can provide power reliably at baseload. The combination of CSP and MED will be highly competitive economically with existing conventionally powered desalination processes. The Barau et al. [78] study suggested that if industry and government focus more on sustainable desalination solutions, then there is a possibility that the LWC for produced water will be well within the economical range. Furthermore, emissions and environmental impacts can be reduced simultaneously. The study outlined a detailed procedure to achieve a sustainable water security target for Arabian countries. Furthermore, Gude et al. [79] analyzed the possibilities of various sustainable approaches in desalination and concluded that geothermal or low-grade heat, utilization of pre-treated wastewater for non-potable options and the hybrid NF-RO-MSF-crystallization unit could obtain water cost as low as 0.3 USD per cubic meter. Furthermore, a study by Ghaffour et al. [80] concluded that renewable energy options for desalination are reliable and can mitigate the carbon emissions from desalination plants, which are presently $0.3 \%$ of total global emissions [80]. 
There have been several advancements in the fields of energy generation, heat transfer, materials and desalination. As reviewed in this study, there is a substantial opportunity for the development of more cost-effective, energy-efficient thermal desalination systems, which can compete with the existing $\mathrm{RO}$ and other membrane-based technologies along with solving the problem of environmental impact, which present technologies, do not take into consideration.

Focusing on the status of renewable energy integration in desalination, it can be deduced that the process is still in the nascent phase. There are sundry of reasons for the slow pace of renewable integration. Firstly, the most widely used renewable globally are wind and solar PV, which face hurdles with intermittent supply, and hence efficient energy storage is a significant challenge which needs to be addressed. Moreover, the social and political hurdles play a vital role in the slower pace of implementation [81]. Countries around the world give priority to economics and finance rather than the environment, and hence the inertia of traditional standard operating processes prevents the large scale integrated projects. Moreover, desalination till now was the necessity of the limited number of countries situated in water-scarce areas whose priority was to meet the local demand first rather than focus on renewable integration [81]. Nanofluids, as discussed, are the engineered suspension of nanoparticles in base fluids with support of surfactant. The physiothermal properties of the resultant nanofluids depend on several factors such as nature of base fluid and surfactant, properties and size of nanoparticles, method of preparing the nanofluids and others. There exists no single rule to define the properties of the nanofluids. Each nanofluid prepared must be characterized separately and prepared for specific applications. For heat transfer-based systems such as power generation, thermal desalination and similar others, nanofluids with high thermal properties are must and hence, MWCNTs, GO and other nanoparticles with higher thermal properties are best suited. Along with thermal properties, the stability of nanofluid for longer duration and at design temperature and pressure range is utmost crucial, and the nanofluid must be optimized, considering all the necessary factors. Nanofluids support development of sustainable desalination systems as these fluids are acknowledged to overcome the thermodynamic limits which are faced by current existing desalination systems. Shahzad et al. [82] developed a standard universal performance ratio-based evaluation method for comparing the different desalination processes. The study showed that merely $2.5-3 \%$ of the primary energy is consumed by thermal desalination processes when combined with power plants. Moreover, the performance ratio of all the existing desalination technologies was found to be in the limit of $10-14 \%$ of the thermodynamic limit which must be ameliorated up to $25-30 \%$ of the thermodynamic limit to meet the 2030 sustainability goals [82].

Designing sustainable desalination systems includes range of factors ranging from powering them with renewable energy systems, dealing with pollution created by brine discharge, efficiency enhancement or performance ratio increment which ultimately means producing more water for same amount of energy input and mitigating all the environmental emissions, if any, created by systems and raw materials utilized during the desalination process. For detailed analysis, LCA (life cycle assessment) of the entire process can be carried out to ensure sustainability at every step of the process. There have been concerns with nanofluids application in thermal systems due to their end of life discharge, stability at high temperature and pressure and effect on treated water if nanofluids come in contact with water. However, all of these issues have been considered during the research. For the experiment, MWCNTs based nanofluids were prepared at various concentrations $(0.01 \%$, $0.05 \%, 0.1 \%$ and $0.5 \%$ ) and their properties such as viscosity, zeta potential, specific heat capacity, density and others were measured. Based on the results, it was reported that nanofluids were stable at higher temperatures and pressures up to the range of their saturation points. Moreover, the boiling point was elevated by a scale of $5-20{ }^{\circ} \mathrm{C}$ after doping on nanoparticles in the base fluid. Furthermore, the application of nanofluids in thermal desalination system (MED) yielded $5 \%$ enhancement in the overall heat transfer coefficient. This result was obtained by plugging in the properties of $0.1 \%$ MWCNT: AG nanofluid in water as base fluid. Furthermore, nanofluids do not pose a threat to the environment at their end of life as nanofluids can be recycled back in the system after ultrasonication of the fluid. Ultrasonication is the process which ensures a homogeneous mixture of the nanoparticles in the fluid. In the case of MWCNT and Arabic Gum (AG) suspension, 
the solution lifetime is 12 months after preparation which can then be ultrasonicated every 12 months again. Table 7, summarizes various nanofluids with their stability period and production process.

Table 7. Summary of the Nanofluids stability for various nanoparticles types, size, loading concentrations and dispersion methods [83]

\begin{tabular}{|c|c|c|c|c|c|c|c|}
\hline Type & Base Fluid & $\begin{array}{l}\text { Synthesis } \\
\text { Process }\end{array}$ & $\begin{array}{l}\text { Particle } \\
\text { Loading } \\
(\text { Vol \%) }\end{array}$ & $\begin{array}{l}\text { Particle } \\
\text { Size } \\
(\mathrm{nm})\end{array}$ & Dispersion Method & Stability & Ref \\
\hline $\mathrm{SiO}_{2}$ & Water & Two-step & 10 & NR & $\begin{array}{l}\text { 3-Glycid oxyl proyl } \\
\text { tri-methy oxy silane } \\
\text { (mass ratio of silane to } \\
\text { silica }=0.115 \text { ) }+ \text { solution } \\
\text { kept at } 50 \mathrm{C} \text { for } 12 \text { hours }\end{array}$ & 12 months & 84 \\
\hline $\mathrm{SiO}_{2}$ & DI water & Two-step & NR & NR & $\begin{array}{l}\text { Oscillated in an } \\
\text { ultrasonic bath for } 12 \\
\text { hours }\end{array}$ & $\begin{array}{l}\text { Several } \\
\text { days }\end{array}$ & 84 \\
\hline $\mathrm{SiO}_{2}$ & $\begin{array}{l}\text { EG, water, } \\
\text { EG/water } \\
\text { solutions, } \\
\text { TO/water } \\
\text { solution }\end{array}$ & Two-step & NR & $\begin{array}{l}10 \quad(\text { for } \\
600 \mathrm{~m}^{2} / \mathrm{g} \\
\text { specific } \\
\text { surface } \\
\text { area) }\end{array}$ & $\begin{array}{l}\text { Ultrasonic disrupter } \\
\text { technique }\end{array}$ & $\begin{array}{l}\text { NR (Not } \\
\text { Reported) }\end{array}$ & 85 \\
\hline $\mathrm{TiO}_{2}$ & EG/ Water & Two-step & $0.5-1.5$ & 50 & $\begin{array}{l}\text { Ultrasonic bath for } 2 \\
\text { hours }\end{array}$ & NR & 86 \\
\hline $\mathrm{TiO}_{2}$ & Water & Two-step & $\begin{array}{l}1,1.5 \text {, and } \\
2.0\end{array}$ & 6 & $\begin{array}{l}\text { Mixture sonicated in } \\
\text { magnetic stirrer followed } \\
\text { by ultrasonic vibration } \\
\text { for } 2 \text { hours }\end{array}$ & NR & 87 \\
\hline $\mathrm{Al}_{2} \mathrm{O}_{3}$ & Water & Two-step & NR & NR & $\begin{array}{l}\text { Ultrasonic pulses of } 100 \\
\mathrm{~W} \text { and } 36 \pm 3 \mathrm{kHz} \text { for six } \\
\text { hours and } \mathrm{pH}=4.8\end{array}$ & $\begin{array}{l}\text { Several } \\
\text { weeks }\end{array}$ & $88-89$ \\
\hline $\mathrm{Al}_{2} \mathrm{O}_{3}$ & Water & Two-step & 20 & 40.2 & $\begin{array}{l}\text { Mixture diluted by } 1 \% \\
\text { nitric acid }+ \text { sonication } \\
\text { continuously four hours } \\
\text { at } 60 \mathrm{~Hz} \text { and } 130 \mathrm{~W}\end{array}$ & One week & 90 \\
\hline $\mathrm{ZnO}$ & Water & Two-step & NR & $150-80$ & $\begin{array}{l}\text { Acetyl acetone }+ \\
\text { sonication for } 10 \text { minutes }\end{array}$ & $\begin{array}{l}9-12 \\
\text { months }\end{array}$ & 89 \\
\hline $\mathrm{ZnO}$ & EG & Two-step & $\begin{array}{l}0.005 \text { and } \\
0.0375\end{array}$ & $<50$ & $\begin{array}{l}\text { Intense Ultrasonication } \\
(200 \mathrm{~W}) \text { for } 100 \text { hours }\end{array}$ & NR & 91 \\
\hline $\mathrm{CuO}$ & Water & Two-step & NR & NR & $\begin{array}{l}\text { Ultrasonication for } 6 \\
\text { hours }+ \text { surfactant Tiron } \\
(\mathrm{CuO}: \text { Tiron }=2.5: 1) \\
\text { Zeta potential }=30 \mathrm{mV} \\
\text { ensured }\end{array}$ & NR & 92 \\
\hline
\end{tabular}


20 of 30

\begin{tabular}{|c|c|c|c|c|c|c|c|}
\hline $\mathrm{CuO}$ & $\begin{array}{l}\text { Distilled } \\
\text { Water }\end{array}$ & Two-step & 0.05 vol \% & NR & $\begin{array}{l}\text { Sodium dodecylbenzene } \\
\text { sulphonate (SDBS) of } 10 \\
\text { wt.\% of nanoparticles } \\
\text { (reason: to prevent } \\
\text { immediate settlement as } \\
\text { CuO NPs have a high } \\
\text { density (6310 } \mathrm{kg} / \mathrm{m}^{3} \text { ) } \\
\text { compared to water }(995 \\
\left.\mathrm{kg} / \mathrm{m}^{3}\right)+ \text { sonication for } 60 \\
\text { minutes }\end{array}$ & $\begin{array}{l}\text { Best with } \\
\text { SDBS }\end{array}$ & 93 \\
\hline $\mathrm{CuO}$ & Water & Two-step & NR & NR & $\begin{array}{l}\text { Ultrasonic }(100 \mathrm{~W}) \text { for } 4 \\
\text { hours }\end{array}$ & 25 days & 94 \\
\hline $\mathrm{Fe}_{3} \mathrm{O}_{4}$ & $\begin{array}{l}\mathrm{H}_{2} \mathrm{O}+\mathrm{EG} \\
(50 \%: \\
50 \%)\end{array}$ & Two-step & NR & NR & $\begin{array}{l}\text { Sonicated for two hours } \\
\text { with vigorous agitation } \\
\text { for } 30 \text { minutes }\end{array}$ & $\begin{array}{l}\text { More than } \\
8 \text { hours }\end{array}$ & 95 \\
\hline $\mathrm{Fe}_{3} \mathrm{O}_{4}$ & Water & Two-step & NR & NR & $\begin{array}{l}\text { Sonication for } 2 \text { hours }+ \\
\mathrm{pH}=3 \text { (use sulfuric acid } \\
\left.\left(\mathrm{H}_{2} \mathrm{SO}_{4}\right)\right)\end{array}$ & NR & 96 \\
\hline$\alpha-\mathrm{Fe}_{2} \mathrm{O}_{3}$ & Water & Two-step & $\begin{array}{l}0.25,0.5,1 \\
2,3, \& 4\end{array}$ & $20-40$ & $\begin{array}{l}\text { Sonication + tetra methyl } \\
\text { ammonium hydroxide }\end{array}$ & NR & 98 \\
\hline $\mathrm{Fe}_{2} \mathrm{O}_{3}$ & Water & Two-step & $0.02 \mathrm{vol}$ & 40 & $\begin{array}{l}\mathrm{PH}=11.1+\mathrm{PEG} \text { as } \\
\text { surfactant }+ \text { magnetic } \\
\text { stirring for } 1 \text { hour }\end{array}$ & 7 days & 97 \\
\hline $\mathrm{Cu}$ & DI water & NR & 9 & NR & $\begin{array}{l}\text { Laureate salts } \quad+ \\
\text { ultrasonic vibration }\end{array}$ & 30 hours & 99 \\
\hline $\mathrm{Cu}$ & NR & Two-step & NR & NR & $\begin{array}{l}\text { Sodium dodecyl sulfate, } \\
\text { cetyl trimethyl } \\
\text { ammonium bromide, } \\
\text { and sorbitan monooleate }\end{array}$ & 24 hours & 100 \\
\hline $\mathrm{Ag}$ & DEG & Two-step & NR & NR & $\begin{array}{l}\text { Continuous stirring \& } \\
\text { agitation for } 5 \text { minutes } \\
\text { by an ultrasonic agitator }\end{array}$ & NR & 101 \\
\hline $\mathrm{Ag}$ & NR & Two-step & NR & NR & $\begin{array}{l}\text { Ultrasonic bath for } 3 \\
\text { hours }\end{array}$ & 48 hours & 102 \\
\hline $\mathrm{Au}$ & $\begin{array}{l}\text { Distilled } \\
\text { Water }\end{array}$ & Two-step & NR & NR & $\begin{array}{l}\text { Solution boiled for } 10 \\
\text { minutes at } 80^{\circ} \mathrm{C}\end{array}$ & NR & 103 \\
\hline $\mathrm{Au}$ & $\begin{array}{l}\text { Water } \\
\text { (laser } \\
\text { ablation) }\end{array}$ & One-step & NR & NR & Stirred magnetically & NR & 104 \\
\hline $\begin{array}{l}\text { MWCNT } \\
\text { (treated with }\end{array}$ & $\mathrm{NR}$ & Two-step & NR & NR & NR & $\begin{array}{l}\text { Several } \\
\text { months }\end{array}$ & 105 \\
\hline
\end{tabular}




\begin{tabular}{|l|l|l|l|l|l|l|l|}
\hline $\begin{array}{l}\text { hydrophilic } \\
\text { functional } \\
\text { groups) }\end{array}$ & & & & & & \\
\hline CNTs & Water & Two-step & NR & NR & 0.2 wt.\% chitosan & 2 months & 106 \\
\hline CNTs & Glycol & Two-step & NR & NR & $\begin{array}{l}\text { Ultrasonic vibration } \\
\text { (Gum Arabic, Tween 80, } \\
\text { and CTAB) }\end{array}$ & 107 \\
\hline
\end{tabular}

Nanofluids for heat transfer and power generation can form an essential part of future desalination systems. Desalination is necessary for the survival of the human race on the planet, but simultaneously, the issues associated with the process must also be solved. The two significant impacts of desalination industry are GHG emissions and concentrated brine discharge. For GHG emissions mitigation, the solution is replacing the fossil-fired power source with renewables. The problem with renewable energy systems is the discontinuous production of energy, which is a major hurdle in the large scale commercialization of renewable integrated desalination projects. Solar thermal energy is an exception to the other renewables where, solar thermal may not only provide baseload power but also can supply process heat round the clock, thereby opening a possibility for combined thermal as well as membrane desalination projects. Considering the other environmental issues of concentrated brine discharge, technologies such as power and chemical production with reverse electrodialysis [108] are in practice. Furthermore, Qatar University (Gas Processing Centre) has developed the modified "Solvay" process in collaboration with QAPCO (Qatar Petrochemical Company). The Solvay process solves the problems of carbon emissions along with issues associated with brine discharge. In this system, the Calcium Oxide is mixed with brine to raise the $\mathrm{pH}$ of the solution to 10, which is then allowed to come in contact with Carbon-Di-Oxide emission stream. The $\mathrm{CO}_{2}$ reacts with Calcium Hydroxide and Sodium Chloride and delivers Calcium Chloride and Sodium Bi-Carbonate. The concentration of brine reduces significantly with Solvay treatment, and the treated water can be utilized for irrigation in addition to enhanced oil recovery [109-110]. Moreover, Hughes et al. [111] developed a technology for producing fertilizers from the concentrated brine. He was able to produce fertilizers from concentrated brine containing divalent metal cations through his patented procedure. Furthermore, Wijayrathne et al. [112] analyzed the by-product of the solar salt production process (Bittern Solution) for the production of a multi-nutrient fertilizer. Hence, the process allows the production of salt and fertilizer from the concentrated brine. The application of nanotechnology for advanced desalination processes is discussed in further detail in the following sections. Significant efficiency improvements can be achieved if the nanofluid based solar system is coupled with the thermal desalination systems. Integrated MSF - MED, MED- TVC and the use of MEDAD (Multi-Effect Adsorption Desalination) combined with nanofluids based heat transfer and power generation can reduce the total energy demand considerably. There is almost a 58\% pumping power reduction using the first two approaches, and the cogeneration saves nearly 20.6\% of the Total Annual Cost (TAC) in comparison to single units. Now, considering the energy and environmental issues together, there is a possibility to develop an eco-friendly sustainable and efficient desalination process. Figure 9 illustrates a conventional hybrid system for desalination as well as for power generation based on concentrated solar power and heating oil as heat transfer fluid. However, if the heat transfer fluid is replaced by designed nanofluids (engineered suspension of nanoparticles in base fluid) with enhanced thermal properties, then a higher GOR (Gain Output Ratio) or PR (Performance Ratio) can be achieved by simultaneously preventing GHG emissions. The new system will have a nanofluid heat transfer loop in place of heat oil circuit, as marked in figure 9. 


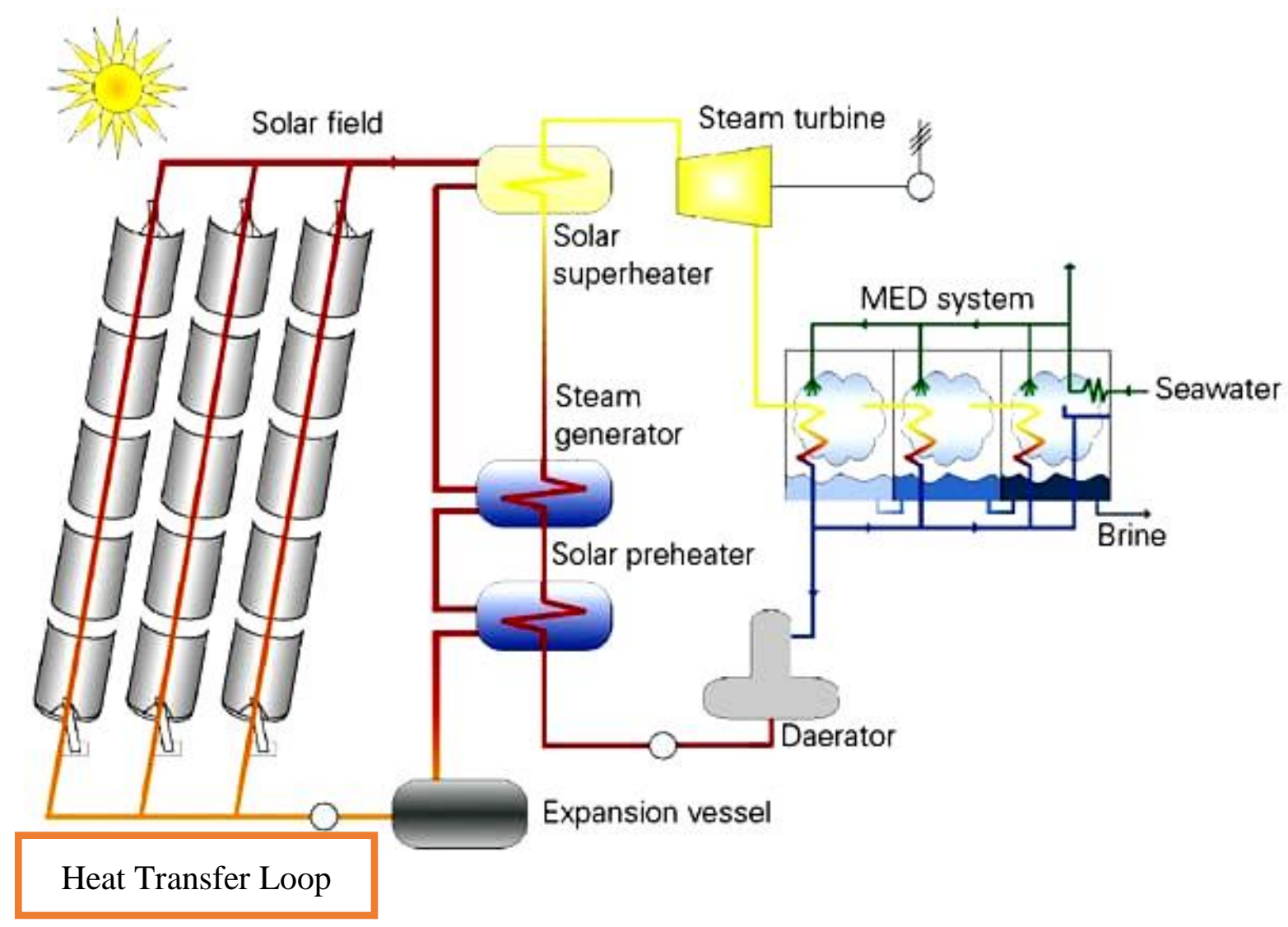

Figure 9. Solar thermal-based power generation and desalination system [113].

\section{Conclusions}

Advanced nanofluids based integrated systems will undoubtedly support the purpose of cost-effective heat transfer processes. The novel MED designs, along with advanced MEDAD systems, will support efficient operations of desalination projects with higher Gain Output Ratio or Performance Ratio. Moreover, if these desalination systems are powered by renewable sources such as CSP technologies which includes LFC (Linear Fresnel Collectors), Parabolic Trough Collectors, Central Receiving Towers or newly developed PV-Thermal technology along with PV, Wind, Tidal and Geothermal, then, the issues of GHG emissions associated with present systems can also be mitigated. As discussed, in this study, the use of nanotechnology can be beneficial, especially in terms of energy efficiency improvements. The experimental analysis showed $5 \%$ enhancement in overall heat transfer coefficient along with enhancement in other vital thermal properties which ultimately reduces CAPEX and size of the system for the same output. The possibility of cost reduction for energy generation with nanofluids has been alluded to in many reported studies. Furthermore, it is necessary to assess the quality of the intake seawater and discharge of brine and assess the brines potential utilization in the chemical and fertilizer industry. Hence, if technologies and policies can both be aligned to achieve sustainable desalination objectives, then, highly efficient, cost-effective renewable desalination technologies with reduced impacts on the environment can be deployed commercially with support from nanofluids. Thus, nanotechnology has great potential to solve the desalination industries problems, and it will support the development of sustainable desalination systems integrated with brine management systems and acquiring power from solar thermal systems. 


\section{List of Abbreviations}

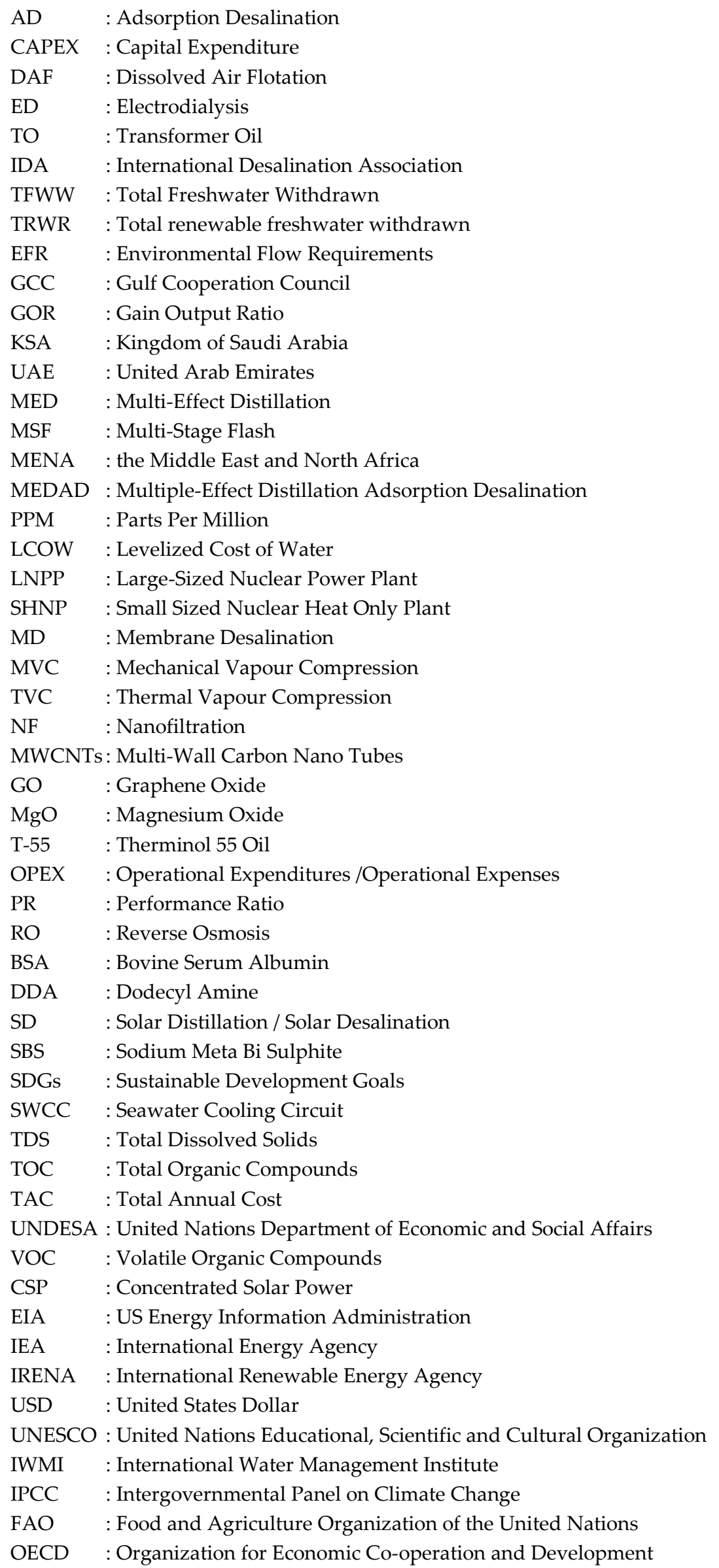




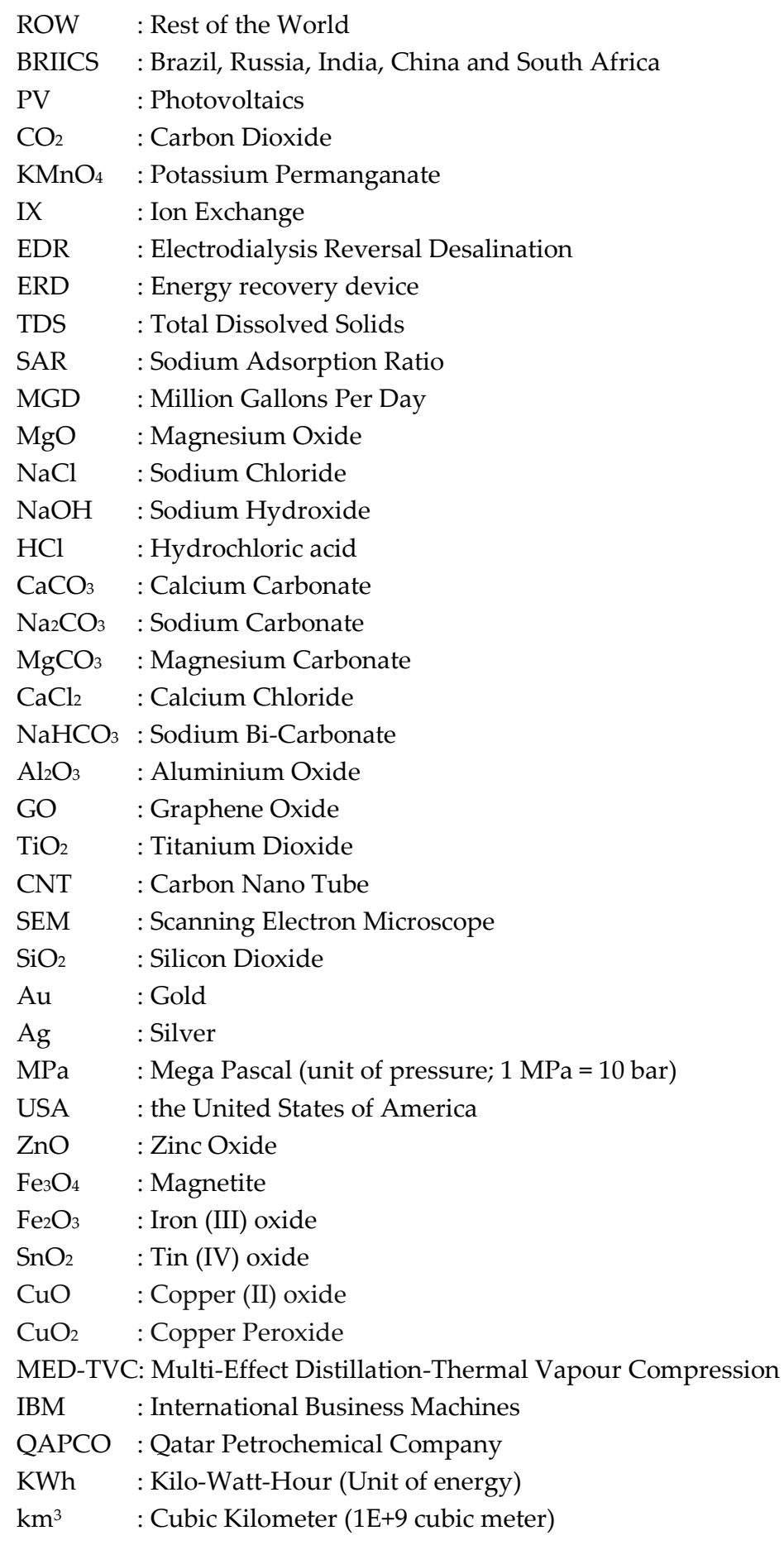

Acknowledgement: The authors would like to acknowledge Hamad Bin Khalifa University (Member of Qatar Foundation) for funding this research.

\section{References}

1. World data lab, Water scarcity clock (2019). Available at: https://worldwater.io/?utm source=google\&utm medium=search\&utm campaign=WaterscarcityData\&c ampaignid $=6444167483 \&$ adgroupid $=77198318295 \&$ adid $=376808482554 \& g \mathrm{clid}=$ Cj0KCQiAl5zwBRCTARIs AIrukdNoi-wWAxdiHfZz8CuBTge4MXwf3fGOqByGFwziwrWDYr5ikX7BiqAaAliPEALw wcB [Accessed on 31 ${ }^{\text {st }}$ December 2019]

2. The United Nations World Water Report, 2016. Water and Jobs. Available at http://unesdoc.unesco.org/images/0024/002439/243938e.pdf [accessed on 29th October 2018] 
3. Dickinson B. $28^{\text {th }}$ February 2011. In 20 years, water demand will exceed supply by 40 percent (population and climate change will put a strain on our water supply). ZDNet-innovation, Available: https://www.zdnet.com/article/in-20-years-water-demand-will-exceed-supply-by-40-percent/ [accessed on $9^{\text {th }}$ April 2018]

4. Ghaffour N, Bundschuh J, Mahmoudi H, Goosen MFA."Renewable energy-driven desalination technologies: A comprehensive review of challenges and potential applications of integrated systems". Desalination (2015), vol. 356, pp. 94-114.

5. International Desalination Association, 2019. Desalination by the numbers. Available at: https://idadesal.org/ [accessed 13th May 2019]

6. Jones E, Qadir M, Van Vliet MTH, Smakhtin V, Kang S-m. The state of desalination and brine production: A global outlook. Science of the total environment-Elsevier, Volume 657, pages 1343-1356, 20th March 2019. DOI: https://doi.org/10.1016/j.scitotenv.2018.12.076

7. UN-Water, 2018. Clean water and sanitation - Progress on level of water stress (global baseline for SDG indicator 6.4.2). Food and agriculture organization of the United Nations. Available at: http://www.unwater.org/publications/progress-on-level-of-water-stress-642/ [accessed on $13^{\text {th }}$ May 2019]

8. Tester JW, Drake EM, Driscoll MJ, Golay MW. Sustainable energy: Choosing among options. London: MIT Press, 2012.

9. Owusu PA, Asumadu-Sarkodie S. A review of renewable energy sources, sustainability issues and climate change mitigation. Cogent Engineering (2006), 3(1), 1167990. https://doi.org/10.1080/23311916.2016.1167990

10. Burn S, Hoang M, Zarzo D, Olewniak F, Campos E, Bolto B, Barron O. "Desalination techniques - A review of the opportunities for desalination in agriculture". Desalination, (2015) vol. 364, pp. 2-16.

11. Lenntech BV. Processes for pre-treatment of seawater. Available at: https://www.lenntech.com/processes/desalination/pretreatment/general/desalination-pretreatment.htm [accessed on 9th April 2018]

12. Dawoud MA, Al Mulla MM. Environmental Impacts of Seawater Desalination: Arabian Gulf Case Study. International Journal of Environment and Sustainability (2012). ISSN 1927-9566 | Vol. 1 No. 3, pp. 22-37

13. Condorchem envitech. Evaporation systems for water desalination. Available at: https://blog-en.condorchem.com/evaporation-systems-water-desalination/\#.XNk3uY4zZPb [accessed on $13^{\text {th }}$ May 2019]

14. DME Desalination Institute. Classification of desalination technologies. Available: https://www.dme-gmbh.de/desalination-technology/technology-basics/classification-of-desalination-tech nologies/ [accessed on 13th May 2019]

15. SIDEM Veolia. Multiple effect distillation process. Available at: http://www.sidem-desalination.com/Process/Thermal-desalination-MED/MED/Process/ [accessed on 13th May 2019]

16. Voutchkov N.Desalination Engineering - Planning and Design. Water Globe Consulting, LLC, WEF Press (For the Water Quality Professional) and Water Reuse Association (Sustainable Solutions for a Thirsty Planet) - Mc Graw Hill (2013), ISBN: 978-0-07-177716-2.

17. Finger CR. From the sea to your house: post-treatment of desalinated water, Abengoa Solar (2014). Available at: http://www.theenergyofchange.com/sea-house-post-treatment-of-desalinated-water [accessed on 14th May 2019]

18. Lenntech. Seawater desalination: Post-treatment processes (2019). Available at: https://www.lenntech.com/processes/desalination/post-treatment/general/desalination-postreatment.htm [accessed on 14th May 2019]

19. Lenntech. Desalination Post-treatment: Neutralization / Remineralization for Drinking water (2019). Available:https://www.lenntech.com/processes/desalination/post-treatment/post-treatments/remineraliza tion.htm [accessed on 14th May 2019]

20. Kim, I.S., Hwang, M., Choi, C. Membrane-based desalination technology for energy efficiency and cost reduction - Desalination sustainability (A technical, socioeconomic, and environmental approach) (2017), pages 31-74. DOI: https://doi.org/10.1016/B978-0-12-809791-5.00002-X

21. Dudda B, Shin D. Effect of nanoparticle dispersion on the specific heat capacity of a binary nitrate salt eutectic for concentrated solar power applications. International Journal of Thermal Science (2013) 69, 37-42. DOI: https://doi.org/10.1016/j.ijthermalsci.2013.02.003 
22. Gavarrell PG. Thermal energy storage for high temperature applications. Doctoral Thesis Departamento de Ingeniería Energética, Escuela Superior de Ingeniería, Universidad de Sevilla, 2017.

23. Zhang, Z., Cai, J., Chen, F., Li, H., Zhang, W., Qi, W. Progress in enhancement of CO2 absorption by nanofluids: A mini-review of mechanisms and current status. Renewable Energy - Elsevier (2018), Volume 118, pages 527-535. DOI: https://doi.org/10.1016/j.renene.2017.11.031

24. Kasaeian, A., Daneshazarian, R., Mahian, O., Kolsi, L., Chamkha, A.J., Wongwises, S., Pop. I. Nanofluid flow and heat transfer in porous media: A review of the latest developments. International Journal of Heat and Mass Transfer - Elsevier (2017). Volume 107, pages 778-791. DOI: http://dx.doi.org/10.1016/j.ijheatmasstransfer.2016.11.074

25. Sharshir SW, Guilong P, Lirong W, Nuo Y, Essa FA, Elsheikh AH, Mohamed SIT, Kabeel AE. Enhancing the solar still performance using nanofluids and glass cover cooling: Experimental study. Applied Thermal Engineering 113 (2017) 684-693. DOI: 10.1016/j.applthermaleng.2016.11.085.

26. Chen W, Zou C, Li X, Liang H. Application of recoverable carbon nanotube nanofluids in solar desalination system: An experimental investigation. Desalination - Elsevier (2017), DOI: https://doi.org/10.1016/j.desal.2017.09.025

27. Wang, M., Fang, G., Liu, P., Zhou, D., Ma, C., Zhang, D., Zhan, J. Fe3O4 @ $3-\mathrm{CD}$ nanocomposite as heterogeneous Fenton-like catalyst for enhanced degradation of 4-chlorophenol (4-CP), Applied Catalysis B: Environmental 188 (2016) 113-122.

28. Shao, L., Wang, X.F., Ren, Y.M., Wang, S.F., Zhong, J.R., Chu, M.F., Tang, H., Luo, L.Z., Xie, D.H. Facile fabrication of magnetic cucurbit[6]uril/graphene oxide composite and application for uranium removal, Chemical Engineering Journal, 286 (2016) 311-319.

29. Kabeel AE, El-Said EMS. Applicability of flashing desalination technique for small-scale needs using a novel integrated system coupled with the nanofluid-based solar collector. Desalination-Elsevier, Volume 333, Issue 1, 2014, Pages 10-22, ISSN 0011-9164. DOI: https://doi.org/10.1016/j.desal.2013.11.021.

30. Chen W, Zou C, Li X, Li L. Experimental investigation of SiC nanofluids for solar distillation system: stability, optical properties and thermal conductivity with saline water-based fluid. International journal of heat and mass transfer (2017), volume 107, pages 264-270. DOI: https://doi.org/10.1016/j.ijheatmasstransfer.2016.11.048

31. Arunkumar T, Raj K, Denkenberger D, Velraj R. Heat carrier nanofluids in solar still - a review. Desalination and water treatment 130 (2018), pages 1-16. DOI: 10.5004/dwt.2018.22972

32. Sahota L, Tiwari GN. Effect of $\mathrm{Al}_{2} \mathrm{O}_{3}$ nanoparticles on the performance of passive double slope solar still. Solar energy, 130 (2016) 260-272. DOI: https://doi.org/10.1016/j.solener.2016.02.018

33. Kabeel AE, Omara ZM, Essa FA. Numerical investigation of modified solar still using nanofluids and external condenser. Journal of the Taiwan Institute of Chemical Engineers, 75 (2017) 77-86. DOI: http://dx.doi.org/10.1016/j.jtice.2017.01.017

34. Elango T, Kannan A, Murugavel KK. Performance studies on single basin single slope solar still with different water nanofluids. Desalination, 360 (2015) 45-51. DOI: https://doi.org/10.1016/j.desal.2015.01.004

35. Gupta B, Shankar P, Sharma R, Baredar PT. Performance enhancement using nanoparticles in the modified, passive solar still. Procedia Technology, 25 (2016) 1209-1216. DOI: https://doi.org/10.1016/j.protcy.2016.08.208

36. Kabeel AE, Omara, ZM, Essa FA, Abdullah AS, Arunkumar T, Sathyamurthy R. Augmentation of a solar still distillate yield via black absorber plate coated with black nanoparticles, Alexandria Engineering Journal, 56 (4) (2017) 433-438. DOI: https://doi.org/10.1016/j.aej.2017.08.014

37. Sain MK, Kumawat G. Performance enhancement of single slope solar still using nano-particles mixed with black paint. Advanced nanoscience and technology, 1 (2015) 55-65.

38. Sharshir, S.W., Peng, G., Wu, L., Yang, N., Essa, F.A., Elsheikh, A.H., Showgi Mohamed, I.T., Kabeel, A.E., 2017. Enhancing the solar still performance using nanofluids and glass cover cooling: an experimental study. Applied thermal engineering, 113 (2017) 684-693. DOI: https://doi.org/10.1016/j.applthermaleng.2016.11.085

39. Negewo D, Bekele Christopher WS - World Bank group. The role of desalination in an increasingly water-scarce world. Technical paper - water global practice, March 2019, Report ID: 135312, Volume 1. Available 
40. Nisan S, Benzarti N. A comprehensive economic evaluation of integrated desalination systems, using fossil-fuelled and nuclear energies and including their environmental costs. International Atomic Energy Agency (IAEA): IAEA, INIS Volume 41 and Issue 6. Reference number: 41021704 and Reference record: 41021686 (2009). Available at: https://www-pub.iaea.org/MTCD/publications/PDF/P 1354 CD/PDF/P 1354.pdf[accessed on 23rd May 2019]

41. Mansour S, Arafat HA, Hasan SW. Brine management in desalination plants - Desalination sustainability-technical, socioeconomic, and environmental approach-Elsevier (2017). ISBN: 978-0-12-809791-5. DOI: http://dx.doi.org/10.1016/B978-0-12-809791-5.00005-5

42. Giwa A, Dufour V, Marzooqi FA, Kaabi MA, Hasan SW. Brine management methods: Recent innovations and current status. Desalination (2017), volume 407, pages: 1-23. DOI: https://doi.org/10.1016/j.desal.2016.12.008

43. Morillo J, Usero J, Rosado D, Bakouri HE, Riaza A, Bernaola FJ. Comparative study of brine management technologies for desalination plants. Desalination (2014), volume 336, pages 32-49. DOI: https://doi.org/10.1016/j.desal.2013.12.038

44. The Great Bubble Barrier. 2019. Available: https:/thegreatbubblebarrier.com/en/bubble-barrier-en/ [Accessed on 31 ${ }^{\text {st }}$ December 2019]

45. TU Delft, 2017. The Ocean Clean Up. Available: https://www.delta.tudelft.nl/article/ocean-cleanup-will-it-deliver [Accessed on 31 ${ }^{\text {st }}$ December 2019]

46. Membracon, UK, 2019. What's the difference between microfiltration, ultrafiltration and nanofiltration. Available at: https://www.membracon.co.uk/blog/whats-the-difference-between-microfiltration-ultrafiltration-and-nan ofiltration/ [Accessed on 31 ${ }^{\text {st }}$ December 2019]

47. Bitar RW, Ahmad A. Issam Fares Institute for Public Policy and International Affairs; solar vs nuclear which is cheaper for water desalination. Policy brief 2/2017; Available at http://website.aub.edu.lb/ifi/publications/Documents/policy memos/2016-2017/20170215 solar nuclear.p df $\quad$ accessed on $9^{\text {th }}$ April 2018]

48. Jung $\mathrm{YH}$, Jeong $\mathrm{YH}$, Choi J, Wibisono AF, Lee JI, Cheon NH. "Feasibility study of a small-sized nuclear heat-only plant dedicated to desalination in the UAE". Desalination (2014), vol. 337, pages 83-97.

49. Frantz C, Seifert B. Thermal analysis of a multi-effect distillation plant powered by a solar tower plant. International Conference on Concentrating Solar Power and Chemical Energy Systems, SolarPACES 2014; Energy Procedia 69 (2015), pages 1928 - 1937.

50. Ali MT, Fath HES, Armstrong PR. A comprehensive techno-economical review of indirect solar desalination. Renewable and Sustainable Energy Reviews(2011), 15(8): pages 4187-4199

51. Shatat M, Riffat S, Ghabayen S. State of the art water desalination technologies using conventional and sustainable energy sources; The 4th International Engineering Conference -Towards engineering of the 21st century (2012). Available at http://research.iugaza.edu.ps/files/2153.PDF (Accessed on 9th September 2018)

52. Casimiro S, Cardoso J, Alarcón-Padilla D, Turchi C, Ioakimidis C, Farinha Mendes J. Modellingmulti-effect distillation powered by CSP in TRNSYS; Energy Procedia 49 (2014) 2241 - 2250.

53. Abdelkareem MA, Assad MEH, Sayed ET, Soudan B. Recent progress in the use of renewable energy sources to power water desalination plants, Desalination (2018), Volume 435, Pages 97-113, DOI: https://doi.org/10.1016/j.desal.2017.11.018

54. Hassabou AH, Spinnler M, Polifke W. Techno-economic Analysis of Medium and Large-scale Desalination Plants Driven by Concentrated Solar Systems in the Mena Region. Energy Procedia (2013), volume 42, pages 735 - 744. DOI: https://doi.org/10.1016/j.egypro.2013.11.076

55. Beitelmal AH, Fabris D. "Off-the-grid solar-powered portable desalination system". Applied Thermal Engineering (2015), vol. 85, pp. 172-178.

56. Farshchi P, (deputy for the marine environment at the Department of Environment Iran). Persian Gulf Salinity Rising. Financial Tribune (31st May 2016). Available at: https://financialtribune.com/articles/people-environment/42562/persian-gulf-salinity-rising [accessed on 9th April 2018] 
57. Todorova V. Desalination threat to the growing Gulf. The National UAE (2009); Available at https://www.thenational.ae/uae/environment/desalination-threat-to-the-growing-gulf-1.553346 [Accessed on 9th April 2018: vtodorova@thenational.ae]

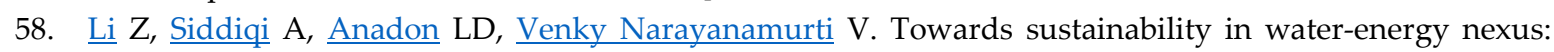
Ocean energy for seawater desalination. Renewable and Sustainable Energy Reviews (2018) - Elsevier, Volume 82, Part 3, Pages 3833-3847. DOI: https://doi.org/10.1016/j.rser.2017.10.087

59. IEA-ETSAP and IRENA. March 2012. Technology Brief I12. Available at: https://www.ctc-n.org/sites/www.ctc-n.org/files/resources/irena-etsap tech brief i12 water-desalination. pdf [accessed on 31st October 2018]

60. Alkaisi A, Mossad R, Barforoush AS. A review of the water desalination systems integrated with renewable energy. 1st International Conference on Energy and Power, ICEP2016, 14-16 December 2016, RMIT University, Melbourne, Australia. Energy Procedia 110 (2017) 268 - 274. DOI: https://doi.org/10.1016/j.egypro.2017.03.138

61. Qiblawey HM, Banat F. Solar thermal desalination technologies. Desalination (2008), Volume 220, Issues 1-3, Pages 633-644. DOI: https://doi.org/10.1016/j.desal.2007.01.059

62. Dongare PD, Alabastri A, Neumann O, Nordlander P, Halas NJ. Solar thermal desalination as a nonlinear optical process. PNAS July 2, 2019, 116 (27) 13182-13187; first published June 17, 2019. DOI: https://doi.org/10.1073/pnas.1905311116

63. Hoffman JE, Dall EP. Integrating desalination with concentrating solar thermal power: A Namibian case study. Renewable Energy 115 (2018) 423-432. DOI: http://dx.doi.org/10.1016/j.renene.2017.08.060

64. Ng KC, Thu K, Oh SJ, Ang Li, Shahzad MW, Ismail AB. Recent developments in thermally-driven seawater desalination: Energy efficiency improvement by hybridization of the MED and AD cycles. Desalination (2015) - Elsevier-Volume 356, Pages 255-270. DOI: https://doi.org/10.1016/j.desal.2014.10.025

65. MEDAD Technologies Pte. Ltd., Singapore, Reg No. 201111303 W, Year of Registration 2012, 6C Tanjong Rhu Road, \#13-02, Singapore 438668.

66. Kyaw T, Chakraborty A, Kim YD, Myat A, Saha BB, Ng KC. Numerical simulation and performance investigation of an advanced adsorption desalination cycle. Desalination 308 (2013) 209-218. DOI: https://doi.org/10.1016/j.desal.2012.04.021

67. Thu K, Kim YD, Shahzad MW, Saththasivam J, Ng KC. Performance investigation of an advanced multi-effect adsorption desalination (MEAD) cycle. Applied Energy (2015), 159, 469-477. DOI: 10.1016/j.apenergy.2015.09.035

68. Mabrouk A, Abotaleb A, Tahir F, Koc M, Al-Rashid A. High-performance MED desalination plants part I: novel design MED evaporator. The International Desalination Association World Congress on Water Reuse and Desalination- São Paulo, Brazil, October 2017.

69. Mabrouk AN, Fath HES. "Techno-economic study of a novel integrated thermal MSF-MED desalination technology". Desalination (2015), vol. 371, pp. 115-125. DOI: https://doi.org/10.1016/j.desal.2015.05.025

70. Jani HK, Modi KV. A review on numerous means of enhancing heat transfer rate in solar thermal-based desalination devices; Renewable and Sustainable Energy Reviews 93 (2018) 302-317.

71. Hussein AK, 2016. Applications of nanotechnology to improve the performance of solar collectors Recent advances and overview. Renewable and Sustainable Energy Reviews 62 (2016) 767-792.

72. Singh T, Hussien MAA, Al-Ansari T, Saoud K, McKay G. Critical review of solar thermal resources in GCC and application of nanofluids for the development of efficient and cost-effective CSP technologies. Renewable and Sustainable Energy Reviews 91 (2018) 708-719.

73. Sharon H, Reddy KS. A review of solar energy-driven desalination technologies. Renewable and Sustainable Energy Reviews 41(2015)1080-1118.

74. Reif H, Alhalabi W. Solar-thermal powered desalination: Its significant challenges and potential.

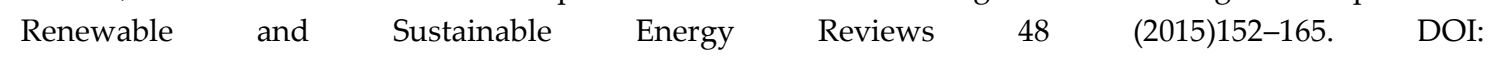
https://doi.org/10.1016/j.rser.2015.03.065

75. Hassaboou AMA. Combination photovoltaic and thermal energy system. The United States Patent Application. Pub. No.: US 2017/0230000 A1. August 10, 2017.

76. Al-Karaghouli A, Renne D, Kazmerski LL. Solar and wind opportunities for water desalination in the Arab regions. Renewable and Sustainable Energy Reviews-Elsevier 13(2009) 2397-2407. DOI: http://dx.doi.org/10.1016/j.rser.2008.05.007 
77. El-Ghonemy AMK. Future sustainable water desalination technologies for Saudi Arabia: A review. Renewable and Sustainable Energy Reviews -Elsevier, 16 (2012) 6566-6597

78. Barau AS, Al-Hosani N. Prospects for environmental governance in addressing sustainability challenges of seawater desalination industry in the Arabian Gulf". Environmental Science \& Policy (2015), vol. 50, pp. 145-154, 2015.

79. Gude VG, Nirmalakhandan N, Deng S. Renewable and sustainable approaches for desalination. Renewable and Sustainable Energy Reviews 14 (2010) 2641-2654

80. Ghaffour N, Reddy VK, Abu-Arabia M. Technology development and application of solar energy in desalination: MEDRC contribution. Renewable and Sustainable Energy Reviews 15 (2011) 4410- 4415

81. Goosen, M.F.A., Mahmoudi, H., Ghaffour, N., 2014. Today's and Future Challenges in Applications of Renewable Energy Technologies for Desalination. Journal Critical reviews in environmental science and technology- Taylor and Francis, Volume 44 (2014), Issue - 9. DOI: https://doi.org/10.1080/10643389.2012.741313

82. Shahzad, M.W., Burhan, M., Ybyraiymkul, D., Ng, K.C. Desalination processes efficiency and future roadmap. MDPI Entropy (2019), 21(1), 84. DOI: https://doi.org/10.3390/e21010084

83. Jama, M., Singh, T., Gamaleldin, S.M., Koc, M., Samara, A., Isaifan, R.J., and Atieh. M.A. Critical Review on Nanofluids: Preparation, Characterization, and Applications; August 2016; Journal of Nanomaterials (Hindawi) Volume 2016, Article ID 6717624, 22 pages; DOI: http://dx.doi.org/10.1155/2016/6717624

84. X.-F. Yang and Z.-H. Liu, "Pool boiling heat transfer of functionalized nanofluid under sub-atmospheric pressures," International Journal of Thermal Sciences, vol. 50, no. 12, pp. 2402-2412, 2011.

85. N. Jamshidi, M. Farhadi, D. D. Ganji, and K. Sedighi, "Experimental investigation on the viscosity of nanofluids," International Journal of Engineering, Transactions B: Applications, vol. 25, no. 3, pp. 201-209, 2012.

86. K. Abdul Hamid, W. H. Azmi, R. Mamat, N. A. Usri, and G. Najafi, "Effect of titanium oxide nanofluid concentration on pressure drop," ARPN Journal of Engineering and Applied Sciences, vol. 10, no. 17, pp. 7815-7820, 2015.

87. T. Kavitha, A. Rajendran, and A. Durairajan, "Synthesis, characterization of TiO2 nanopowder and water-based nanofluids using two-step method," European Journal of Applied Engineering \& Scientific Research, vol. 1, pp. 235-240, 2012.

88. M. Chandrasekar, S. Suresh, and A. C. Bose, "Experimental investigations and theoretical determination of thermal conductivity and viscosity of $\mathrm{Al}_{2} \mathrm{O}_{3} /$ water nanofluid," Experimental Thermal and Fluid Science, vol. 34, no. 2, pp. 210-216, 2010.

89. S. Soltani, S. G. Etemad, and J. Thibault, "Pool boiling heat transfer of non-Newtonian nanofluids," International Communications in Heat and Mass Transfer, vol. 37, no. 1, pp. 29-33, 2010.

90. P. E. Gharagozloo and K. E. Goodson, "Temperature-dependent aggregation and diffusion in nanofluids," International Journal of Heat and Mass Transfer, vol. 54, no. 4, pp. 797-806, 2011.

91. M. Kole and T. K. Dey, "Thermophysical and pool boiling characteristics of ZnO-ethylene glycol nanofluids," International Journal of Thermal Sciences, vol. 62, pp. 61-70, 2012.

92. K. Rohini Priya, K. S. Suganthi, and K. S. Rajan, "Transport properties of ultra-low concentration CuO-water nanofluids containing non-spherical nanoparticles," International Journal of Heat and Mass Transfer, vol. 55, no. 17-18, pp. 4734-4743, 2012.

93. J. J. Michael and S. Iniyan, "Performance analysis of a copper sheet laminated photovoltaic thermal collector using copper oxide-water nanofluid," Solar Energy, vol. 119, pp. 439-451, 2015.

94. N. Kannadasan, K. Ramanathan, and S. Suresh, "Comparison of heat transfer and pressure drop in the horizontal and vertical helically coiled heat exchanger with $\mathrm{CuO} /$ water-based nanofluids," Experimental Thermal and Fluid Science, vol. 42, pp. 64- 70, 2012.

95. M. Sheikh Bahai, M. Nasr Esfahany, and N. Etesami, "Experimental investigation of pool boiling of $\mathrm{Fe}_{3} \mathrm{O}_{4}$ /ethylene glycol-water nanofluid in an electric field," International Journal of Thermal Sciences, vol. 62, pp. 149-153, 2012.

96. L. S. Sundar, M. T. Naik, K. V. Sharma, M. K. Singh, and T. C. S. Reddy, “Experimental investigation of forced convection heat transfer and friction factor in a tube with $\mathrm{Fe}_{3} \mathrm{O}_{4}$ magnetic nanofluid," Experimental Thermal and Fluid Science, vol. 37, pp. 65-71, 2012. 
97. Y. Vermahmoudi, S. M. Peyghambarzadeh, S. H. Hashemabadi, and M. Naraki, "Experimental investigation on heat transfer performance of $\mathrm{Fe}_{2} \mathrm{O}_{3} /$ water nanofluid in an air-finned heat exchanger," European Journal of Mechanics -B/Fluids, vol. 44, pp. 32-41, 2014.

98. A. Karimi, M. Goharkhah, M. Ashjaee, and M. B. Shafii, "Thermal conductivity of $\mathrm{Fe}_{2} \mathrm{O}_{3}$ and $\mathrm{Fe}_{3} \mathrm{O}_{4}$ magnetic nanofluids under the influence of the magnetic field," International Journal of Thermophysics, vol. 36, no. 10-11, pp. 2720-2739, 2015.

99. Y. Xuan and Q. Li, "Heat transfer enhancement of nanofluids," International Journal of Heat and Fluid Flow, vol. 21, no. 1, pp. 58-64, 2000.

100. H. Peng, G. Ding, and H. Hu, "Effect of surfactant additives on nucleate pool boiling heat transfer of refrigerant-based nanofluid," Experimental Thermal and Fluid Science, vol. 35, no. 6, pp. 960-970, 2011.

101. E. Tamjid and B. H. Guenther, "Rheology and colloidal structure of silver nanoparticles dispersed in diethylene glycol," Powder Technology, vol. 197, no. 1-2, pp. 49-53, 2010.

102. T. Parametthanuwat, S. Rittidech, and A. Pattiya, "A correlation to predict heat-transfer rates of a two-phase closed thermosyphon (TPCT) using silver nanofluid at normal operating conditions," International Journal of Heat and Mass Transfer, vol. 53, no. 21-22, pp. 4960-4965, 2010.

103. J. John, L. Thomas, B. Rajesh Kumar, A. Kurian, and S. D. George, "Shape-dependent heat transport through green synthesized gold nanofluids," Journal of Physics D: Applied Physics, vol. 48, no. 33, Article ID 335301, 2015.

104. S. Soltaninejad, M. S. Husin, A. R. Sadrolhosseini et al., "Thermal diffusivity measurement of Au nanofluids of very low concentration by using photoflash technique," Measurement, vol. 46, no. 10, pp. 4321-4327, 2013.

105. L. Chen, H. Xie, Y. Li, and W. Yu, "Nanofluids containing carbon nanotubes treated by the mechanochemical reaction, "Thermochimica Acta, vol. 477, no. 1-2, pp. 21-24, 2008.

106. P. Garg, J. L. Alvarado, C. Marsh, T. A. Carlson, D. A. Kessler, and K. Annamalai, “An experimental study on the effect of ultrasonication on viscosity and heat transfer performance of multiwall carbon nanotube-based aqueous nanofluids," International Journal of Heat and Mass Transfer, vol. 52, no. 21-22, pp. 5090-5101, 2009.

107. M. Zhaoguo, W. Daxiong, L. Wang, H. Zhu, and Q. Li, "Carbon nanotube glycol nanofluids: photo-thermal properties, thermal conductivities and rheological behaviour," Particuology, vol. 10, no. 5, pp. 614-618, 2012.

108. Tedesco M, Cipollina A, Tamburini A, Micale G, Helsen J, Papapetrou M. REA Power: use of desalination brine for power production through reverse electrodialysis. Desalination and Water Treatment (2015), 53(12), 3161-3169. DOI:10.1080/19443994.2014.934102

109. El-Naas M. QU-CENG team develops a new method for 'reject brine' management. The Peninsula Qatar's daily newspaper, 20 Nov 2017. Available at: https://www.thepeninsulaqatar.com/article/20/11/2017/QU-CENG-team-develops-new-method-for-\%E2\% 80\%98reject-brine\%E2\%80\%99-management [accessed on 22 $2^{\text {nd }}$ July 2019]

110. El-Naas M. Process for the capture of carbon dioxide and desalination. The United States Patent Application. Patent No.: US 10, 118, 843 B2. November 6, 2018.

111. Hughes WB. Method of providing fertilizer from brines. The United States Patent Application. Patent number 4,576,627. March 18, 1986.

112. Wijayarathne U, Perera SAS, Wasalathilake K, Vidanage P. Development of a Multi-Nutrient Fertilizer from Liquid Waste of Solar Salt Manufacturing Process. IEEE Xplore - 2015 Moratuwa Engineering Research Conference (MERCon). DOI: 10.1109/MERCon.2015.7112314

113. Zachary, J., Layman, C.M., Adding Desalination to Solar Hybrid and Fossil Plants - Bechtel Power Corp. (2010). Available at: https://www.powermag.com/adding-desalination-to-solar-hybrid-and-fossil-plants/?pagenum=5

[Accessed on $2^{\text {nd }}$ January 2020] 